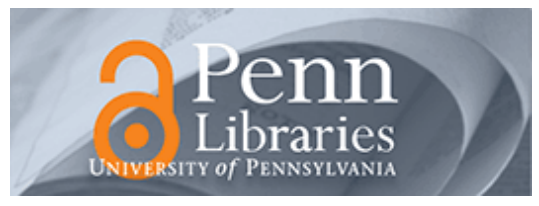

University of Pennsylvania

ScholarlyCommons

Finance Papers

Wharton Faculty Research

2013

\title{
Do Public Equity Markets Matter in Emerging Economies? \\ Evidence From India
}

Radhakrishnan Gopalan

Todd A. Gormley

University of Pennsylvania

Follow this and additional works at: https://repository.upenn.edu/fnce_papers

Part of the Finance Commons, and the Finance and Financial Management Commons

\section{Recommended Citation}

Gopalan, R., \& Gormley, T. A. (2013). Do Public Equity Markets Matter in Emerging Economies? Evidence From India. Review of Finance, 17(5), 1571-1615. http://dx.doi.org/10.1093/rof/rfs036

This paper is posted at ScholarlyCommons. https://repository.upenn.edu/fnce_papers/326

For more information, please contact repository@pobox.upenn.edu. 


\title{
Do Public Equity Markets Matter in Emerging Economies? Evidence From India
}

\author{
Abstract \\ Do public equity markets serve an unique role that is not easily served by other forms of financing in \\ emerging economies? We analyze this question using the collapse of India's equity market in 1997, which \\ provides an exogenous shock to firms' ability to issue equity. We find that both public and private firms \\ exhibit higher bankruptcy rates and lower growth after 1997. The decline in growth is greater among firms \\ with more external finance needs and fewer tangible assets. Overall, the evidence suggests that public \\ equity markets are an important, not easily replaced, source of finance in emerging economies. \\ Disciplines \\ Finance | Finance and Financial Management
}




\title{
Do Public Equity Markets Matter in Emerging Economies? Evidence from India
}

\author{
Radhakrishnan Gopalan*and Todd A. Gormley ${ }^{\dagger \ddagger}$
}

September 30, 2012

\begin{abstract}
Do public equity markets serve a unique role that is not easily served by other forms of financing in emerging economies? We analyze this question using the collapse of India's equity market in 1997, which provides an exogenous shock to firms' ability to issue equity. We find that both public and private firms exhibit higher bankruptcy rates and lower growth after 1997. The decline in growth is greater among firms with more external finance needs and less tangible assets. Overall, the evidence suggests that public equity markets are an important, not easily replaced, source of finance in emerging economies.

Journal of Economic Literature Classification Numbers: G01, G20, O16, E44.

Keywords: Public Equity Markets, Emerging Economies, Crises, India

\footnotetext{
* Olin Business School, Washington University in St. Louis

${ }^{\dagger}$ The Wharton School, University of Pennsylvania

${ }^{\ddagger}$ We thank Jose Luis Peydro Alcalde, Francois Derrien, Mariassunta Giannetti, Raj Iyer, David Matsa, Loriana Pelizzon, Enrico Perotti, and other participants at the 2009 AFA Annual Meeting (San Francisco), 9th Annual Darden International Finance Conference, 2008 FIRS Biannual Finance Conference (Anchorage), CAF-FIC-SIFR Conference on Emerging Market Finance (Stockholm), CREI, CEPR, and JFI Conference on Finance, Growth and Structure (Barcelona), 2007 CEPR European Summer Symposium in Gerzensee evening session (Switzerland), the IMF methodology workshop, World Bank Finance Seminar, and the Washington University finance lunch series for their most helpful comments. The Prowess data used in this paper was provided by the IMF through their visiting scholars program. The analysis and conclusions in this paper, however, are our own and do not necessarily represent those of the IMF or IMF Policy. All remaining errors are also our responsibility.
} 
Financial economists have long debated the relative importance of banks and capital markets for financial development. Existing research finds that both bank-based and market-based systems have similar effects on the growth rate of industries and firm investment (Beck and Levine, 2002). One possible interpretation of this finding is that banks and capital markets are substitutes and the absence of one is easily bridged by the other. In other words, the absence of a vibrant stock market might have little effect on economic growth. Morck et al. (1990) express this colorfully when they hypothesize the capital markets to be just a 'sideshow', not central to firms' financing or investment choices. This view of capital markets, however, runs counter to a long held view, first expressed in Keynes (1936), that non-fundamental movements in stock prices can affect a firm's level of investment, and hence, economic growth.

While there are a number of studies looking at whether banks play an independent role in affecting a firm's growth and investments (e.g. Ongena et al., 2003; Khawaja and Mian, 2008), there is little comparable research looking at the independent role of public equity markets. In an important study on why firms go public around the world, Kim and Weisbach (2008) find that public equity markets are a prominent source of finance; on average, firms use 28.4 cents of every dollar raised in an initial public offering (IPO) on capital expenditures and R\&D. It is unclear, however, whether public equity markets serve a unique role not easily served by other sources of finance. Answering this question is difficult in that it requires one to isolate shocks to a firm's access to equity markets that does not affect other sources of finance and is not driven by a change in investment opportunities. ${ }^{1}$ In this paper, we try to answer this question by using the collapse of India's equity market in 1997, to analyze the importance of public equity markets for a firm's investments and growth in emerging economies. Aiding our identification, as we discuss below, the collapse was confined to the equity market and did not affect firm's access to other sources of

\footnotetext{
${ }^{1}$ As noted in Baker et al. (2003), just analyzing correlations between stock price movements and investment can be misleading since these stock price movements likely reflect changes in expected cash flows.
} 
finance such as bank debt.

Public equity markets may be particularly important source of finance in emerging economies. The banking sector in these countries is often dominated by government-owned banks that favor financing large, established, and politically connected firms (Beck et al., 2005; Borensztein and Lee, 2002; Khwaja and Mian, 2005; La Porta et al., 2002; Morck and Nakamura, 1999). To the extent the public equity markets are less subject to capture by politicians and large industrial incumbents, they may provide an attractive source of finance for small, young firms with investment opportunities (Rajan and Zingales, 2003). The concentrated nature of banking markets in these countries may also increase banks' ability to extract rents (Rajan, 1992), further increasing the attractiveness of public equity markets. Public equity markets may also aid the development of a private equity sector (Black and Gilson, 1998).

Our setting offers a number of unique advantages in assessing the importance of public equity markets in emerging economies. First, the collapse of India's equity market in 1997 provides an exogenous shock to firms' access to public equity finance that is largely unrelated to firms' investment opportunities. During the first half of our sample period, 1992-1996, India's equity market was 'hot'; over 4,000 firms went public and more than 200 firms completed a secondary equity offering (SEO). But in 1997, both the IPO and the SEO markets collapsed and remained relatively inactive through 2002. Only 252 IPOs and SEOs were completed between 1997 and 2002. Helping us isolate a shock to firm's access to public equity markets, the collapse was triggered by a combination of factors largely unrelated to firms' investment opportunities: regulatory changes that made it more difficult for firms to go public, the withdrawal of foreign portfolio investments following the Asian financial crisis, and the high profile failure of a few public firms that shook investor confidence. 
The financial turmoil did not appear to originate from or result in any significant negative shocks to the real economy. Overall GDP averaged six percent annual growth both prior to the fall in the number of equity issues, 1993 to 1996, and afterwards, 1997 to 2000, and outstanding bank credit grew at an average annual rate of 16.6 percent from 1993 to 1996 and 16.4 percent from 1997 to 2000 . The continued growth of the aggregate economy in the face of the fall in the number of equity issues reflects both the smaller share of the private corporate sector in the Indian economy and the greater reliance of the non-Government firms on bank financing. Thus, while a fall in equity issues adversely affected the performance of equity-dependent firms (as shown later) and long-run growth (because some small, high-growth firms may fail to find alternative funding sources), it was not large enough to have a sizable or immediate impact on overall GDP.

The second advantage of our empirical setting is the availability of detailed firm-level financial data on public and private firms. Unlike in the U.S., even unlisted firms in India, are required to file financial statements with the regulator. The data for private firms enables us to understand which types of firms go public in an emerging economy and to test for differential responses among firms more likely to depend on equity financing following the stock market's collapse. This difference-indifference approach allows us to better isolate the independent role of equity markets and to provide novel evidence on whether the public equity market affects the financing and investment choices of private firms. Our data set also includes information on a firm's affiliation with a business group, which we use as another proxy for a firm's dependence on external equity finance. An important caveat about our data set is that it does not include the smallest firms of the Indian economy. This is due to the minimum size requirement for inclusion imposed by our data source, Prowess. We discuss this in greater detail in our Data Section.

The final advantage of analyzing India is that although its equity market is large, it is otherwise similar to other emerging economies. India's equity market ranked tenth in the world at the end 
of 2007, in terms of market capitalization, and had the largest number of IPOs among countries studied by Kim and Weisbach (2008). ${ }^{2}$ Despite the size of its stock market, India's broader financial system resembles that of many other emerging markets in that it is relatively underdeveloped and dominated by large, government-owned banks. ${ }^{3}$ Analyzing the equity market in this environment is likely to provide general insights on how public equity markets may affect firm investments and financing choices in other emerging economies.

To analyze whether the equity market collapse affected investment levels and firms' performance, we conduct a battery of tests. We begin by documenting which firms go public in India, how firms utilize the IPO proceeds, and which firms are able to issue equity after the market's collapse. This analysis sheds light on which firms may be most affected when equity becomes scarce. We then use multiple proxies to identify public and private firms that are most likely to depend on external equity capital and study how their performance and financing choices change following the equity market's collapse relative to firms less likely to rely on equity finance. Observing a relative deterioration in performance for these firms after the equity market's collapse would suggest that they are unable to replace public equity with alternate sources of finance.

Our evidence indicates that the public equity markets in India expanded access to finance for small, young firms between 1992 and 1996. Firms that go public prior to the collapse are smaller, in terms of total sales, and younger, as measured by age since incorporation, relative to the average private firm in our sample. ${ }^{4}$ Firms that go public also appear to have more investment opportunities relative to firms that choose to remain private, and firms appear to use the equity markets to finance these growth opportunities. Relative to both other public and private firms, the

\footnotetext{
${ }^{2}$ Source: http://www.world-exchanges.org/statistics/annual/2007/domestic-market-capitalization.

${ }^{3}$ Bank credit to GDP was $25 \%$ and market capitalization to GDP was 23\% (Demirguc-Kunt and Levine, 2001), and government banks accounted for 86.3 percent of bank assets in 1992 (Source: www.rbi.org.in).

${ }^{4}$ This evidence differs significantly from IPO studies in more developed countries such as Italy and Germany (Pagano et al., 1998; Fischer, 2000).
} 
firms that go public exhibit significant increases in capital expenditure and sales around the time of their IPO and reduce their use of expensive forms of finance such as trade credit.

Small, young firms' ability to grow using equity appears to decrease significantly after the equity market's collapse in 1997. After 1996, only larger, older firms with greater investment opportunities and past capital expenditures successfully undertake an IPO. This shift in firms that go public suggests that post-1996 the public equity markets were available as a financing option only for the less risky and more established firms. In many ways, the market structure shifted in 1996 from a hybrid AIM type market, ${ }^{5}$ where young firms were able to go public at low cost, to a more mature NYSE type market, where this was less true.

The equity market's collapse is associated with weaker performance among private firms most likely to depend on external equity capital. We find that private firms with characteristics similar to pre-1997 IPO firms, such as young, non-group firms located in high investment industries, experience a fall in profit margins, capital expenditure and sales growth, and an increase in bankruptcy rates after 1996 relative to other private firms. Private non-group firms, which do not have access to a group's internal capital market, are affected more by the market's collapse. Given there is no ex-ante reason for group-affiliated and unaffiliated firms' investment opportunities to respond differentially to the market's collapse, this suggests that the decline in growth among private firms is due to a shift in access to equity finance and that the AIM type market that existed in India prior to 1997 served an important role in enabling young firms to raise outside equity and grow.

The collapse of the public equity market is also associated with a decline in performance among public firms most likely to depend on a secondary equity offering (SEO). Public firms that resemble pre-1997 SEO firms experience a fall in capital expenditure, profit margins and an increase in leverage following the market collapse relative to other public firms less likely to do an SEO.

\footnotetext{
${ }^{5}$ AIM is the London Stock Exchange's international market for smaller growing companies.
} 
Firms that go public immediately prior to the collapse, which are more likely to require follow-on equity financing after the equity market's collapse, also exhibit sharp declines in sales growth rates, profitability and increases in leverage beginning in 1997 relative to firms that went public in earlier years and are less likely to need follow-on equity financing. Consistent with lack of external equity finance affecting performance, the fall in sales growth among firms more likely to depend on equity finance is also more severe for firms from industries that depend more heavily on external finance, firms with lower asset tangibility, and non-group firms.

Overall, the evidence regarding firms' financing choices and performance following India's equity market's collapse in 1997 suggests that public equity markets have the potential to expand access to finance and foster greater investment in emerging economies. Our findings also suggest that the public equity markets may be an important source of finance in emerging economies, and for many firms, they are not always easily replaced by alternate sources of finance.

Our focus on public equity markets in emerging economies is related to a number of recent empirical papers. Beck and Levine (2002) finds evidence that both bank-based and arm's length financial markets have similar effects on growth, whereas Gormley et al. (2011) provides evidence that public debt markets can act as a spare tire for bank-based financing during a banking crises. Bekaert et al. (2005) and Henry (2000a, 2000b) find evidence that allowing foreign participation in domestic equity markets may also have beneficial affects for domestic firms in these economies. Our paper builds on this existing literature by analyzing how equity markets generally affect a firm's investment, performance, and financing choices in emerging economies, and whether equity markets play an independent role in promoting growth that is not easily replaced by alternate sources of finance.

Our focus on India's equity market collapse is also related to the papers that estimate the 
effect of a banking crisis on bank dependent borrowers (e.g. Ongena et al., 2003; Paravisini, 2008; Khwaja and Mian, 2008). Unlike these papers, we study how a crisis in the capital markets affects investments and growth in the corporate sector. Our evidence also highlights which firms may be more dependent on equity finance and how capital markets may provide an important source of finance for these particular firms.

This paper is also related to a growing, but relatively small, empirical literature regarding a firm's decision to go public. The two closest papers are Pagano et al. (1998) and Chemmanur et al. (2010). Similar to this paper, both papers analyze the going-public decision using ex-ante characteristics and ex-post performance of the IPO firms. But unlike this paper, both papers focus on relatively developed financial markets, Italy and the U.S., respectively. Our focus on an emerging market with an underdeveloped financial system helps us understand the role of public equity markets when the alternate sources of finance are underdeveloped. Furthermore, the market collapse in 1997 helps us design sharper tests of whether the public equity market affects the real economy. ${ }^{6}$

Finally, this paper is related to two recent papers that also study the Indian IPO market during the same time period as ours. Bubna and Prabhala (2007) studies the effect of introducing book building as a method of issuance on pricing of the IPO shares, while Marisetty and Subrahmanyam (2010) looks at the pricing and subsequent stock performance of group and non-group IPOs.

The remainder of the paper proceeds as follows. Section 1 describes India's economy and public equity markets during our sample period. Section 2 describes the data, and Section 3 reports our estimates on which firms go public in India and their post-IPO performance. Section 4 analyzes how both public and private firms' financing choices and performance change following the equity

\footnotetext{
${ }^{6}$ Other, but less directly related empirical papers that have looked at the going public decision include Fischer (2000), Boehmer and Ljungqvist (2004), Bharath and Dittmar (2010) and Aslan and Kumar (2010).
} 
market's collapse in 1997. Section 5 discusses some additional tests and robustness checks. Section 6 concludes.

\section{India's Public Equity Market}

In April 1992, India's public equity market was greatly deregulated with the passage of the SEBI Act. This Act abolished the existing regulator, the Comptroller of Capital Issues, and established the Securities and Exchange Board of India (SEBI) as the new regulatory agency for India's capital markets. The initial set of guidelines issued by SEBI allowed almost all firms to freely price their IPOs and decide on the size of the issue in consultation with merchant bankers. Only firms without a three-year track record of profitability and not belonging to a group with existing profitable firms were subject to price controls. These guidelines have since been amended periodically and now go under the name of "Disclosure and Investor Protection Guidelines." Prior to 1992, the Comptroller of Capital Issues controlled the pricing and the size of all the issues allowed and imposed a minimum profitability track record for firms to go public.

The easing of regulation made it easier for firms to access the equity market, leading to a surge in IPOs and SEOs between 1992 and 1996. 4,368 firms went public and 218 firms accessed the SEO market between 1992 and 1996. Some of India's fastest growing firms in the information technology sector today, such as Infosys Technologies Limited (NASDAQ listed with a market capitalization of about $\$ 30$ billion) went public during this period.

In 1997, the volume of IPOs and SEOs significantly dropped and remained low for a number of years. The total number of IPOs reported in SDC Platinum fell from 1,134 in 1996 to 66 in 1997 and the number of SEOs fell from 23 in 1996 to 6 in 1997. This drop in IPO and SEO activity persisted for a number of years. The number of IPOs and SEOs during the five year period 1998- 
2002 amounted to 180, an average of 36 per year. This represents a sharp drop from the average of 990 IPOs and SEOs per year between 1992 to 1996.

The decline in equity issues appears driven by multiple factors. One factor was efforts by the SEBI to tighten the rules governing which firms could issue equity. Some of these rules were based on the recommendations of the Malegam Committee. The rules were put in place between 1995 and 1996 and restricted IPOs to companies with a three year track record of dividend payment unless the company had its project appraised by a bank that has at least a 10 percent stake in the project (SEBI, 1997 and 1998). At the same time, companies that wanted to do a SEO that would increase their equity capital by more than 500 percent now had to satisfy the same criteria as firms attempting to do an IPO. ${ }^{7}$

The second factor that contributed to the decline in equity issues was a collapse in investor confidence and the supply of equity finance. There was a significant decline in foreign capital inflows following the Asian financial crisis of 1997. Foreign institutional investor inflows fell from $\$ 3.3$ billion in $1996-97$ to $\$ 1.8$ billion in 1997-98 to - $\$ 66$ million in 1998-99 (SEBI, 2006). ${ }^{8}$ The foreign investor outflows was also accompanied by an outflow of domestic funds from equity markets. The fraction of equity in household wealth in India fell from $9.5 \%$ in 1994-95 to $4.18 \%$ in 1996-97. The domestic outflows were primarily driven by a collapse in investors' confidence which was precipitated by the discovery of some 'fly by night' IPOs in 1995 and 1996 that defrauded investors. ${ }^{9}$

\footnotetext{
${ }^{7}$ There was also a corresponding change in regulation that allowed firms to make a public debt issuance without first making a public equity issuance. This change, however, does not appear to explain the drop in equity issuances. Public debt issuances also exhibited a sharp drop in 1997 and did not recover to pre-collapse levels until 2001. Likewise, we do not see firms substituting into private placement of equity; private capital issues also declined in 1996-97. See Appendix Table A-I for details on financial flows to the private sector during the 1990s, and see Appendix Table A-II for a complete listing of changes in primary equity market issuance regulations between 1993 and 1998.

${ }^{8}$ The dates represent financial years, which run from April to March in India.

${ }^{9}$ One of the notable scandals of this period was M.S. Shoes East Limited which went public in September 1992 and whose main promoter, Pavan Sachdeva was arrested in April 1995 and accused of violating SEBI guidelines and bribing SEBI officials. Other notable scandals of that period include Rupangi Impex Ltd. (RIL) and Magan Industries Ltd. (MIL). In both cases, the dominant shareholders were found to be guilty of price manipulation. See newspaper reports Business Line July 15, 1997, "Funds still at a premium for corporate sector", and July 5, 1997, "Why the bourses have gone dry?" for more details on the sudden shift in investor confidence.
} 
The collapse of the equity market, however, does not appear to originate from any shift in firms' investment opportunities or demand for equity finance. The turmoil in the equity markets and regulatory changes were not accompanied by a fall in the growth rate of the manufacturing sector, bank credit, or the overall economy. Both the manufacturing sector and overall GDP averaged six percent annual growth rates from 1996 to 2000, and bank loans grew at 16.4 percent. During the previous four years, these growth rates were 4.2, 4.0 and 16.6 percent respectively. The equity market collapse had a limited effect on the broader economy because the non-Government corporate sector comprised a small share of the Indian economy (about 47\%). And within these firms, more than $50 \%$ belong to family owned business group with access to internal equity from other member firms. Furthermore, non-Government Indian firms predominantly access external financing from banks. The total outstanding banking credit at the end of 1995-96 fiscal year was Rs. 2.5 trillion whereas the total amount of money raised from the public equity markets in 1995-96 was Rs. 120 billion, which was only about 1 percent of GDP (Appendix Table A-I). ${ }^{10}$

Because the equity market's collapse in 1997 was largely unrelated to firms' investment opportunities or their ability to fund these investments through other sources of finance, we are able to isolate a negative shock to firms' ability to raise external equity. The collapse hence provides a relatively clean setting to study whether public equity markets matter for firm investments and growth. In particular, a decline in observed investment levels and performance among firms most likely to rely on equity finance after 1997 would suggest that public equity markets are an important source of finance for firms and not easily replaced by alternate sources of capital.

A post-collapse decline in firm performance, however, could also reflect two other possibilities:

\footnotetext{
${ }^{10}$ Of course, whether the equity market's collapse had an immediate effect on aggregate growth is impossible to know since the counterfactual, GDP growth absent the collapse, is not observed. Moreover, the inability of some equity-dependent firms to obtain financing after the equity market's collapse may have long-run effects on growth that are harder to quantify. For example, some of India's fastest growing firms today, such as Infosys Technologies Limited, first went public prior to the market's collapse. The failure or delay for such firms to raise financing may have had long-run effects on growth.
} 
the unraveling of 'fly-by-night' firms that helped contribute to the collapse in investors' confidence or the equity market correctly anticipating a decline in future investment opportunities. In Section 5, we do a number of robustness checks to test these two alternative possibilities, but do not find evidence consistent with these explanations. We now describe our data.

\section{Description of Data}

We use two main sources of data to analyze the impact of India's equity market collapse. Our first source is a list of IPOs and SEOs by Indian firms from SDC Platinum. For every Indian IPO and SEO listed in SDC with an issue date between 1992 and 2002, we collect the firm name and issue date. We restrict our sample to the post-1991 period because of the government restrictions on firms' ability to issue equity prior to 1992. We also do not collect IPO and SEO data after 2002 as our firm-level financial data (described below) does not cover firms after 2002. The 1992 to 2002 window, however, provides us with five years of pre-collapse data (1992-1996) and six years of post-collapse data (1997-2002).

Our second data source, Prowess, provides annual financial data and other descriptive variables for firms, including their industry classification, year of incorporation, and group affiliation. Compiled by the Centre for Monitoring Indian Economy (CMIE), Prowess is a panel of both listed and unlisted public limited companies with assets plus sales greater than 40 million Rupees (approx. $\$ 900,000)$. In India, firms can be incorporated either as a private limited company or a public limited company. The key distinction between the two types of incorporation is that the shares of a private limited company are not freely transferable and there must be less than 50 shareholders (excluding past and present employees). Therefore, a company that wishes to issue shares widely to the public and be listed on an exchange must first be incorporated as a public limited company. Because of these restrictions, the majority of the private limited companies are unlikely to 
satisfy the listing requirements of SEBI and hence their exclusion from Prowess is unlikely to affect the conclusions from our analysis in Section 3. Prowess covers between 2,000 to 6,000 listed and unlisted firms each year, and about twenty-five percent of the firms are unlisted firms.

To better capture the subsample of firms capable of issuing equity, we restrict our sample to only firms in Prowess with a book value of total assets greater than Rs. 50 million. SEBI guidelines stipulate a minimum networth of Rs. 30 million for firms to go public. Since networth data is missing for most of our sample firms, we use the book value of total assets as an alternate sorting variable. We also drop firms that are identified by Prowess as government- or foreign-owned, leaving between 2,000 and 5,000 domestic firms in our sample each year.

Using firm names, we then manually match the SDC data on IPOs and SEOs with our financial data. Of the 4,607 IPOs reported in SDC between 1992 and 2002, we are able to match 2,572 to Prowess. We believe the main reason for the less than perfect match between SDC and Prowess is the minimum size requirement imposed by Prowess. Prowess only covers firms with assets plus sales greater than Rs. 40 million. Consistent with the unmatched IPOs likely being too small, we find that while we are able to match $63.5 \%$ of the IPOs in the largest decile in terms of issue size, we are only able to match $49.3 \%$ of the IPOs in the smallest size decile. Of the 2,572 IPOs that we are able to match with Prowess, we are able to obtain financial data for the year before the IPO for only 1,405 firms. Here again, we believe the main reason to be the minimum size stipulation by Prowess. Because our analysis requires pre-IPO data, the IPOs without pre-IPO data are excluded from our analysis. We lose an additional 230 IPOs because of our minimum asset size stipulation resulting in our final sample of 1,175 IPOs. $^{11}$

In Table I, we provide the year-wise distribution of the full sample and the sub-samples of public

\footnotetext{
${ }^{11}$ A yearly breakdown of IPOs in SDC along with the matches to Prowess can be found in the online appendix to the paper.
} 
firms, private firms, IPOs, and SEOs. The number of private firms in our sample is uniformly distributed across the years, with around 700 to 1,500 private firms each year. Prowess does not actually identify whether a firm is public or private. While a firm's ownership is easy to ascertain for those that go public during our sample period, we use two methods to identify the ownership status of all other firms in our sample. First, we classify a firm as being public if it reports stock price data for any of the years during the sample period. Second, we classify firms as public if they report having non-zero shareholdings under the category 'Indian Public Holdings'. This category includes dispersed holdings by small shareholders and only public firms are likely to have such shareholders. Financial data for a large sample of private firms is one of the novel aspects of our data and allows us to assess the impact of the equity market collapse on this subset of firms. We will use this data to identify the types of private and public firms likely to use equity finance and how these firms behave following the market's collapse.

Our final sample includes firm-level financial data for 1,175 IPOs and 231 SEOs between 1992 and 2002, and the observed pattern of equity issues captures the equity market collapse in 1997. Coinciding with the collapse in investor confidence in 1997, the trends in the number of IPOs and SEOs show a distinct break in 1997. Only 81 firms in our sample do an IPO between 1997 and 2002 compared to 1,094 between 1992 and 1996. Likewise, only 22 SEOs are completed after 1996 compared to 209 from 1992-1996.

In Table II, we provide descriptive statistics for our sample. Average characteristics of all firms are reported in Column (1), and statistics for public and private firms are reported separately in Columns (2) and (3). As expected, private firms are generally smaller in size. The average value of total assets for the firms in our sample is Rs. 4.456 billion. (approximately $\$ 100$ million), while for private firms, the average value is just Rs. 806.6 million (approximately $\$ 18$ million). There are relatively small differences in age, profitability, or leverage between public and private firms, but 
there is some evidence that private firms have higher average capital expenditures and are more likely to be affiliated with a group.

\section{Going Public in India, 1992-2002}

Before studying the impact of the equity market's collapse in 1997, we first analyze the average characteristics of firms that go public and their post-IPO performance. This analysis helps us identify which firms issue equity in India and how the proceeds are used. The findings also provide a benchmark for our later analysis on how firms' behavior changes when equity finance becomes scarce after 1996.

\subsection{EX-ANTE CHARACTERISTICS OF IPO FIRMS}

We first estimate the average characteristics of private firms that choose to go public relative to all other private firms that remain private. To do this, we follow existing literature and estimate the following model:

$$
\mathrm{IPO}_{i t}=\gamma X_{i t-1}+\delta_{t}+\varepsilon_{i t}
$$

where the dependent variable $I P O_{i t}$ is a dummy variable that takes a value one for firm $i$ at time $t$ if that firm did an IPO in that year and zero otherwise. Only private firms are included in the regression, and following the previous literature that studies firms' going public decision, $X$ is a set of firm characteristics and includes, Log(Age), Industry Debt/TA, Industry Investment, and lagged values of $\log ($ Sales $)$ and $E B I D T A / T A$. We also include an indicator for whether a firm is affiliated with a domestic group, Group, in our specification. $\delta_{t}$ represents a set of time dummies and is included to capture country-level macro effects. The standard errors are corrected 
for heteroscedasticity and autocorrelation. ${ }^{12}$

Our results indicate that the IPO market in India was an attractive source of finance for profitable, young, and small firms. As seen in Column (1) of Table III, private firms that go public are likely to be smaller in terms of sales, younger, and more profitable relative to the average private firm in our sample. The smaller size and younger age of IPO firms differs from existing studies of firms' going public choice, such as Pagano et al. (1998) and Chemmanur et al. (2010). These studies find that it is usually the older, larger private firms that go public. One potential explanation for the difference is our focus on an emerging market, where the alternate sources of finance, such as bank finance, are less available for small, young firms.

We also find that the firms that go public are more likely to have investment opportunities and a greater need for equity finance. Firms that go public are more likely to be from industries with greater investment levels [Column (1)] and from industries with higher market to book ratios [Column (2)], another potential proxy for investment opportunities. ${ }^{13}$ In Column (3), we repeat our regression using the Rajan and Zingales (1998) index, $R$-Z Index, as a measure of a firm's dependence on external finance and find that firms that go public are more likely to be from industries that depend on external finance. Firms that go public in India are also less likely to be affiliated with a business group. Since groups are known to improve their member firms' access to finance through the internal capital market (Gopalan et al., 2007), this is consistent with the IPO being an important source of finance. ${ }^{14}$ IPO firms are also less likely to operate in industries where

\footnotetext{
${ }^{12}$ Since we are only interested in identifying cross-sectional characteristics of firms that undertake an IPO, we do not include firm fixed effects. Including these fixed effects would eliminate our ability to analyze the effect of characteristics, such as group affiliation, that are fixed over time. In later regressions, where we analyze changes in firms' performance, we will include firm fixed effects.

${ }^{13}$ Since the market-to-book ratio is also a measure of the pricing level in an industry, with a higher value indicating potential over-pricing of firms in that industry, the positive co-efficient on Industry Market-to-Book may also indicate market timing by the firms that go public.

${ }^{14}$ Given that group firms are less likely to go public, we test to see if there are significant differences in the characteristics of group and non-group firms that go public. Consistent with group firms having alternate sources of capital and going public at a later stage in their life cycle, we find that group firms that go public are older, larger, and with greater investment opportunities. The estimates can be found in the paper's online appendix.
} 
debt finance is more readily available, as captured by industries with a higher average leverage ratio.

All of the findings are robust to alternative specifications. In Column (4) we repeat our estimation with a Logit model instead of an OLS model, and in Column (5) we repeat our estimation with Cox proportional hazard model. In both cases, we find similar results. To control for the possibility that our findings might be driven by promoters of young firms attempting to cash out and exit the firm (rather than to raise external financing), we also repeated our analysis after dropping the 44 IPOs in our sample that had a sale of secondary shares at the time of the IPO; the findings are robust to excluding these IPOs. ${ }^{15}$

\section{$3.2 \quad$ POST-IPO PERFORMANCE}

In this section, we investigate the post-IPO performance of firms that go public relative to all other firms. Our objective is to understand how firms that go public use the IPO proceeds, which will help us understand how these and similar firms may be affected by the collapse of the equity market. Specifically, we estimate the following model:

$$
y_{i t}=\beta_{0}+\sum_{s=-7}^{-1} \Gamma_{s} \operatorname{Pre}-\operatorname{IPO}(-\mathrm{s})_{i t}+\sum_{s=1}^{10} \Gamma_{s} \operatorname{Post}-\mathrm{IPO}(\mathrm{s})_{i t}+\alpha_{i}+\delta_{t}+\varepsilon_{i t}
$$

where Pre-IPO(-s) is an indicator that equals one if it is -s years prior to a firm's IPO, and Post$I P O(s)$ is an indicator that equals one if it is $s$ years following a firm's IPO. All firms, both public and private, are included in the estimation, ${ }^{16}$ and since our sample includes at most seven years of

\footnotetext{
${ }^{15}$ The estimates can be found in the online appendix to the paper. In unreported tests, we also estimate a model similar to Chemmanur et al. (2010) by augmenting the specification in Column (3) of Table 3 with additional independent variables that include: market share, lagged sales growth, lagged capital expenditure, industry Herfindal index to proxy for industry competition, asset tangibility, and industry risk as proxied by volatility of sales growth. Inclusion of these additional variables does not affect the results reported in Table 3, and we find that firms with higher past capital expenditure, lower asset tangibility and those from industries with greater sales volatility are more likely to go public. We do not include the additional variables in our baseline specification, however, because their inclusion significantly reduces the size of the sample.

${ }^{16}$ Because firms that remain private and firms that are already public are inherently different from the firms that choose to go public, the appropriate control group to benchmark the performance of newly public firms against is
} 
data prior to a firm's IPO and ten years of post-IPO data, the model is fully saturated with the year of going public being the excluded category. The inclusion of firm fixed effects, $\alpha_{i}$, ensure that each indicator is estimated using only variation in performance around a firm's IPO year relative to all other firms, and time dummies, $\delta_{t}$, control for country-level trends. Our dependent variables, $y$, are Capital Expenditure, Log(Sales), Debt/TA, and Trade Credit/Sales. For each dependent variable, we plot the point estimates of $\Gamma_{s}$ for three years prior to and five years after the IPO in Figure 1. Five percent confidence intervals, estimated with standard errors clustered at the firm level are also reported.

The estimates of Equation (2) suggest that firms issuing equity subsequently fund new capital expenditure. As seen in Figure 1, firms exhibit an increase in capital expenditure one year prior to going public $(t=-1)$ and a dramatic spike in the IPO year. The point estimates for capital expenditures in the pre- and post-IPO years are significantly lower than that in the year of the IPO $(t=0)$. Firms going public appear to return to a steady-state level of capital expenditure in about two years after the IPO. While this level is lower than the pre-IPO level, it is comparable to that of other public firms. In unreported tests we find that both the mean and median level of capital expenditure for newly public firms in years $t=2,3,4$, and 5 are not significantly different from that of all other public firms. ${ }^{17}$

Sales also grow significantly one year after the IPO $(t=1)$ and continue to grow at a faster rate until about three years after the IPO. The increased growth is economically large. Relative to all other firms, firms going public exhibit a thirty percent higher sales growth in the three years after their IPO.

unclear. However, we obtain results similar to those reported when we alternatively restrict the control group to only private or only public firms.

${ }^{17}$ Since these specifications include firm fixed effects, it is not possible to make inferences about the differences in levels between IPO firms and all other firms directly from the estimates presented in Figure 1. The estimates in Figure 1 only tell us how firms that went public trended differently in the years around their IPO, $t=0$, relative to firms that did not go public. Since $t=0$ is the excluded year, it is set to zero by default. 
The increase in capital expenditure and sales prior to and immediately following the IPO shows that on average firms went public in India to raise money to fund investments. Consistent with this we also find that less than $2 \%$ of the IPOs during the time period involve sale of secondary shares. One view of the IPO market development in India is that before the collapse, the market was predominantly used as an exit vehicle by the promoters of small and young firms. The less frequent issue of secondary shares and the increase in capital expenditure and sales during the time of the IPO are inconsistent with this view.

The estimates presented in Figure 1 also indicate a shift in financing sources following an IPO. We see an immediate decrease in leverage in the year of the IPO - consistent with an infusion of new equity capital - but a rather quick return to pre-IPO levels. The increase in leverage to pre-IPO levels, despite a significant increase in assets, suggests that firms are able to successfully lever up their new equity capital. Trade Credit/Sales is also significantly lower for the IPO firms in the years following the IPO $(t>1)$. This suggests that the public equity market enables these firms to be less reliant on costly trade credit.

In unreported tests we use a model similar to (1) and (2) to estimate which firms do a SEO and how firm performance changes following a SEO. We find that similar to an IPO, small, young, non-group firms with investment opportunities are more likely to do a SEO. Firms that do an SEO also have higher average sales and capital expenditure in the year of a SEO, but the sample size is smaller and the estimates are not statistically significant at conventional confidence levels.

\section{Collapse of the Equity Market}

Our findings so far indicate that small, young, non-group firms with investment opportunities are more likely to issue equity in India, and their behavior after issuing equity is consistent with them 
using the public equity market to fund investment opportunities. We now turn our attention to determine whether the public equity market plays an independent role in affecting a firm's growth and investments or whether its absence is easily bridged by alternate sources of finance. We answer this question by analyzing the effects of the equity market collapse in 1997.

We start by analyzing how private firms' performance and financing change following the collapse. First, we analyze whether the characteristics of firms that go public after 1996 differs from that of the 1992-1996 period. Shifts in the characteristics of firms that go public after 1996 will shed light on which private firms are likely to lose access to equity finance following the collapse in investor confidence and the increase in regulatory restrictions. Second, we analyze changes in investment, financing, and profitability of private firms most likely to be affected by the market collapse. In particular, we analyze the differential response of private firms most likely to have gone public after 1996 if the equity market had remained strong, as proxied by having characteristics similar to pre-1997 IPO firms, and of non-group private firms, which are more likely to be affected by the market's collapse since they do not have access to a group's internal capital market.

We next analyze how investment, financing, and profitability of public firms changes following the market collapse. We look at three sets of public firms. First, we compare the performance of public firms with characteristics similar to pre-1997 SEO firms relative to other public firms. Second, similar to our analysis of private firms, we compare non-group, public firms to group-affiliated, public firms. Here again, we expect the market collapse to have a more adverse impact on nongroup, public firms. Finally, we analyze the performance of firms that went public immediately prior to the equity market's collapse relative to firms that went public in earlier years of our sample. We study the newly public firms because these firms are more likely to seek follow-on equity financing (Eckbo and Masulis, 1995), and hence, be affected by the equity market's collapse. 


\subsection{WHO GOES PUBLIC AFTER THE COLLAPSE?}

As seen in Table I, the number of IPOs decreased dramatically in 1997 with only a few firms going public. But who were these firms? To answer this question, we re-estimate Equation (1) differentiating between pre- and post-1996 IPOs. This is done in Column (2) of Table IV, where we add interactions between Post-1996 IPO, a dummy variable that identifies IPOs that occur after 1996, and firm characteristics for age, size, and industry investment. ${ }^{18}$ In Column (1), we report the results of the regression from Table III for comparison purposes.

The estimates suggest that small and young firms are less likely to go public after 1996. Firms that go public after 1996 are, on average, older relative to firms that go public prior to the market's collapse [Table III, Column (2)]. The finding is also robust to using Logit [Column (3)] and a Cox proportional hazard model [Column (4)]. Moreover, the combined estimates of Log(Age) and Log $($ Age $) \times$ Post-1996 IPO suggest that firms that go public after 1996 are, on average, older than firms that remain private. The estimates in Column (4) also indicate that firms that go public after 1996 are relatively larger than both firms that go public prior to 1996 and firms that remain private, and all estimates suggest that the firms going public after 1996 are from industries with greater investment levels.

These results suggest that after 1996, only well established firms from industries with high investment needs go public, and the IPO market's role as a source of finance for small, young firms was likely diminished. As noted earlier, this shift appears driven by the collapse in investor confidence, a decline in foreign inflows, and regulatory changes rather than any shift in investment opportunities. ${ }^{19}$ The absence of the public equity market as a funding source may adversely affect

\footnotetext{
${ }^{18}$ In unreported regressions, we estimate a model with a full set of interaction terms, but find that none of the other interactions are statistically significant.

${ }^{19}$ Again, the distribution of firms going public pre- and post-collapse is unaffected by the exclusion of the 44 IPOs with a coinciding sale of secondary shares. These results are reported in the paper's online appendix.
} 
the performance of small, young private firms. We now analyze this possibility.

\subsection{THE IMPACT ON PRIVATE FIRMS}

If the IPO market served an unique role in firm financing, then the cooling of the IPO market and the subsequent fall in IPO volumes may adversely affect the performance of private firms that are otherwise strong candidates to do an IPO. This would happen if these firms were planning an IPO prior to the collapse but are no longer able to go public and the proceeds from going public are not easily replaced by alternate sources of capital. Newspaper articles at the time appear to support this possibility. In an article from a weekly India Today dated December 31, 1996, it was argued that "roughly Rs. 5,670 crore (a crore is equal to ten million) worth of projects have been dropped after SEBI's acknowledgement card had been received. Based on a market survey, Prime's Director Pritivi Haldea estimates that the future of another Rs. 8,300 crore worth of projects is uncertain but may well be dropped, given the market conditions." 20 The adverse effect of the IPO market's collapse may also be worsened if the availability of alternate sources of capital, such as venture capital, is dependent on the presence of a strong IPO market (Black and Gilson, 1998).

To evaluate this possibility, we analyze the post-collapse change in performance of private firms most likely to benefit from a liquid public equity market, as captured by having characteristics similar to pre-1997 IPO firms, relative to all other private firms. Specifically, we estimate the following equation:

$$
y_{i t}=\beta_{0}+\beta_{1}\left[\operatorname{Prob}(\mathrm{IPO})_{i} \times \operatorname{Post}_{-1996}\right]+\delta_{t}+\alpha_{i}+\varepsilon_{i t},
$$

where $\operatorname{Prob}(\mathrm{IPO})_{i}$ is the estimated probability of a private firm $i$ going public after 1996, and Post-1996 is an indicator equal to one for the years 1997 and beyond. The sample is restricted to

\footnotetext{
${ }^{20}$ See "Stock Markets: Depressed Sentiments to Prevail Until A Serious Attempt is Made to Kick-Start the Economic Reforms Process", India Today, December 31, 1996.
} 
firms that remain private through 2002, and standard errors are clustered at the firm level.

The coefficient of interest, $\beta_{1}$, will capture any post-1996 performance shift among likely IPO candidate firms relative to less likely IPO candidates. The firm-level fixed effects will control for any average differences across firms, and the year fixed effects will capture any country-level trends. The estimation is a difference-in-difference, and $\beta_{1}$ will properly estimate the impact of the equity market's collapse on these likely IPO candidates if in the absence of the equity market's collapse, the post-1996 performance trend of these firms would be similar to that of other private firms. This assumption seems plausible as the equity market's collapse in late-1996 does not appear to coincide with any other shift in domestic financial policy or economic growth that would differentially affect likely IPO firms.

To identify private firms likely to benefit from a public equity market, we first re-estimate Equation (1) using IPOs from 1992-1996. ${ }^{21}$ Our estimates on the likelihood of doing an IPO are obtained using a firm's age, group-affiliation, and amount of investment in the firm's primary industry along with industry fixed effects. We do not include any firm-level financial variables in the new specification as we are interested in estimating the impact of the IPO market's collapse on these variables. $^{22}$ The results of this estimation are reported in Column (1) of Table V. As before, age and group-affiliation are negative predictors of going public prior to 1997, whereas operating in an industry with higher levels of investment is a positive predictor.

Using the coefficient estimates from this model, we predict the yearly probability of going public for the subset of firms that are still private by the end of 1996. For each firm $i$, we then average its predicted probability for the years 1992-96 to construct its Prob(IPO). We use the average proba-

\footnotetext{
${ }^{21}$ We only estimate firms' likelihood of going public after 1996 using data from prior to the equity market's collapse because using post-collapse data would cause a potential endogeneity bias. For example, the market's collapse and the reduced ability to go public may affect investment in some industries, which would in turn affect our estimate of Prob(IPO).

${ }^{22}$ In unreported tests, we find that including these variables does not qualitatively affect our subsequent findings.
} 
bility of doing an IPO prior to the market's collapse to avoid spurious correlation between changes in the probability of going public over time - which is mainly due to changes in average industry investment and firm age - and post-collapse changes in a firm's performance. Using Prob(IPO), we then estimate Equation (3) for a variety of performance measures: Sales Growth, Capital Expenditures, Debt/TA, EBIDTA/Sales, and Bankruptcy. Bankruptcy is an indicator variable that equals 1 in year $t$ if the firm files for bankruptcy with the Bureau for Industrial and Financial Reconstruction (BIFR) and 0 otherwise. ${ }^{23}$ The results are presented in Table V, Columns (2)-(6).

Private firms resembling pre-1997 IPO firms suffer relatively larger setbacks after the equity market's collapse. The negative coefficient on Prob(IPO) $\times$ Post-1996 in Column (2) indicates a significant fall in the sales growth of these private firms relative to all other private firms after 1996. The magnitude of the drop is economically significant. A one standard deviation increase in the probability of doing a IPO is associated with a post-1996 drop in sales growth to $14 \%$ from the sample average of $45 \%$. There is also a fall in capital expenditure [Column (3)], a drop in profitability [Column (5)], and an increase in the bankruptcy rates of these firms [Column (6)]. This evidence suggests that the IPO market serves as an important source of capital for these firms. There is also evidence that these firms respond to the market's collapse by using more debt [Column (4)], but the lower growth and investment suggest that, at least for these private firms, debt and other sources of finance are not a perfect substitute for the public equity market. ${ }^{24}$

Since Prowess does not cover the smallest firms, the effect we document is only for those private firms large enough to be covered by Prowess. To the extent the smaller private firms not covered by Prowess may have greater information and agency problems and hence greater difficulty in accessing

\footnotetext{
${ }^{23}$ The BIFR is India's federal bankruptcy court where firms subject to the Sick Industrial Company Act of 1985 (SICA) must file for bankruptcy. SICA governs the vast majority of bankruptcy cases in India since it applies to all firms that employ more than 50 workers and have been in operation for over five years.

${ }^{24}$ Since our objective is to understand whether the equity market collapse differentially affected the performance and financing pattern of firms that resemble pre-1997 IPO firms, and not necessarily to understand the channel through which this occurs, we do not estimate a simultaneous equation system.
} 
alternative sources of external finance, the effects we document for the relatively larger firms may understate the true magnitude of the adverse consequences of the market's collapse.

The timing of the reduced performance coincides with the equity market's collapse. Figure 2 plots the point estimates from a modified version of Equation (3), where we allow the effect of $\operatorname{Prob}(I P O)$ to vary by year. There is no difference in the growth rates of private firms that resemble pre-1997 IPOs as compared to other private firms prior to the market's collapse. But after the collapse, private firms that resemble pre-1997 IPOs and hence those most likely to benefit from a strong IPO market tend to grow at a much slower rate than other private firms. This diminished growth begins in the year of the collapse and continues for the duration of the sample time period. The precise timing of the reduced growth suggests that it is less likely to be caused by any omitted firm or industry characteristic.

One possible concern with our prior estimates is that they may be driven by changes in firms' investment opportunities rather than the collapse of the equity market. This could happen if the pre-1997 IPOs are clustered in a few industries that experience a reduction in investment opportunities after 1997. Our data, however, suggests that such industrial clustering is unlikely to explain our findings. IPOs occur in 93 of the 119 different 3-digit SIC industries captured in our sample of private and public firms.

To further exclude this possibility, we next compare the performance of group-affiliated and unaffiliated private firms after the equity market's collapse. This test helps mitigate the above concern for two reasons. First, there is no ex-ante reason to suspect that the investment opportunities of group and non-group firms would differentially change around the time of the equity market collapse. Second, because of their access to a group's internal capital market and greater access to debt capital from banks, group-affiliated firms are likely less dependent on public equity issues for 
financing investment, and hence, less likely to be affected by the IPO market's collapse. ${ }^{25,26}$

To test the collapse's differential effect on non-group firms, we re-estimate (3) after substituting Prob(IPO) with Non Group, where Non Group is a dummy variable that identifies firms unaffiliated with business groups. We also include controls for a firm's size, Log(Assets), and investment opportunities, as captured by Industry Investment. The results, reported in Panel B of Table V, are consistent with the public equity market providing an important source of finance for non-group firms. Relative to group-affiliated private firms, the non-group private firms exhibit a significant fall in the sales growth [Column (1)], capital expenditures [Column (2)], and profitability [Column (4)] following the equity market's collapse in 1996. These results are also economically significant. The results in Column (1) indicate that non-group private firms have a 29 percentage point lower sales growth rate as compared to group-affiliated private firms. In comparison, the mean sales growth rate of private firms in the sample is $44 \%$.

\subsection{THE IMPACT ON PUBLIC FIRMS}

In this section, we analyze whether the equity market collapse affected the investment and financing choices of public firms. As shown in Table I, the SEO market exhibited a sharp decline in activity after 1996. If the SEO market serves an important role in providing equity finance for public firms, then the collapse of the equity market is likely to affect the performance of public firms that depend more heavily on external equity finance. To analyze this possibility, we estimate the differential impact of the equity market's collapse on public firms more reliant on external equity finance relative to public firms less reliant on external equity finance.

\footnotetext{
${ }^{25}$ Group-affiliated firms' weaker dependence on equity finance is supported by our earlier estimates that show that such firms are less likely to go public in India. The greater availability of debt capital for group firms is also implied by the results in Gopalan et al. (2007) and by the fact that, ceteris paribus, group firms in India have higher leverage ratios.

${ }^{26}$ Since we use group affiliation as one of the variables to identify likely IPO candidates in our tests in Panel A, our tests in Panel B are not entirely independent of those in Panel A. We still perform these tests to ensure that our results in Panel A are not solely driven by changes in industry investment opportunities.
} 
We first identify public firms likely to do a SEO using a model similar to (1) for the sample period 1992-96. In this case, our dependent variable is a dummy variable that identifies public firms that do a SEO in a particular year, $S E O$. The results of this estimation are reported in Column (1) of Panel A of Table VI. We find that only the extent of investment in a firm's industry is a significant predictor of completing a SEO. A firm's age and group affiliation provide little predictive power for SEOs [Table VI, Column (1)]. ${ }^{27}$

Using the coefficients from this estimation, we then predict the yearly probability of a public firm doing a SEO and calculate the average probability of a firm undertaking a SEO between 1992 and 1996, Prob(SEO). Using this predicted likelihood of a public firm doing a SEO as our proxy for a public firm's dependence on external equity finance, we re-estimate Equation (3) using all public firms in our sample after substituting $\operatorname{Prob}(S E O)$ in place of $\operatorname{Prob}(I P O)$. The results are presented in Columns (2)-(6) of Panel A of Table VI.

The estimates indicate that public firms resembling pre-1997 SEO firms suffer relatively larger setbacks after the equity market's collapse. The negative coefficient on Prob(SEO) $\times$ Post-1996 in Table VI, Column (2) indicates a significant fall in the sales growth rate of these firms relative to all other public firms after 1996. The magnitude of the drop is economically large. A public firm with a one standard deviation higher probability of doing a SEO has an average sales growth rate that is 9 percentage points lower after 1996. In comparison, the median sales growth rate among public firms in our sample is $12 \%$. There is also a decrease in capital expenditure [Column 3], an increase in leverage [Column (4)], and a drop in profitability [Column (5)]. These findings strongly suggest that the SEO market served as an important source of capital for some public firms in

\footnotetext{
${ }^{27}$ In unreported tests we find that when we employ a hazard model, we find that similar to our IPO results, young firms not affiliated with a business group are more likely to do a SEO. We believe the lack of significance of these covariates in the linear probability model may be because of the fewer SEOs as compared to IPOs in our sample. We have 231 SEOs as compared to 1,175 IPOs. We compensate for the poor prediction of our SEO model by performing additional tests using alternate ex-ante proxies for a public firm's dependence on external equity. These results are reported in Sections 4.4 and 5.
} 
India, and despite an attempt by firms to substitute into using more debt, the adverse turn in the market had a negative impact on the performance of firms most likely to tap the equity market. ${ }^{28}$

We next compare the performance of firms affiliated with business groups with unaffiliated firms. These tests help ensure that our earlier results are not driven by changes in the industry investment opportunities that coincide with the SEO market collapse. Since group firms have access to their internal capital market and better access to bank finance, we expect group firms to be affected less by the collapse of the SEO market. To test this, we re-estimate (3) after substituting Prob(SEO) with Non Group, a dummy variable that identifies non-group firms, and adding $\log ($ Assets $)$ and Industry Investment as additional controls.

The results in Panel B of Table VI suggest that non-group, public firms were affected more by the adverse turn in the equity market. The negative coefficient on Non Group $\times$ Post-1996 in Column (1) indicates that there is a significant fall in the sales growth rate of unaffiliated firms relative to group-affiliated firms. There is also a relatively larger fall in the capital expenditure levels of these firms [Column (2)] and a relatively larger drop in profitability [Column (4)].

\subsection{THE IMPACT ON NEWLY PUBLIC FIRMS}

Another set of public firms likely to be disproportionately affected by the equity market's collapse are newly public firms, which are more likely to do follow-on equity offerings (Eckbo and Masulis, 1995) than other public firms. If the newly-public firms are not able to replace the planned SEOs with other sources of capital, then their performance may be adversely affected.

An upward shift in bankruptcies among newly public firms after 1996 provides some preliminary evidence that SEO market collapse adversely affected these firms. This is seen in Table VII, where

\footnotetext{
${ }^{28}$ In an unreported test similar to the one reported in Figure 2, we also check to ensure there is no pre-existing differential trend prior to 1997 among public firms most likely to be adversely affected by the markets' collapse in 1997. The estimates confirm that the decline in performance among the firms most likely to do a SEO does not begin to occur until 1997. These estimates are available from the authors upon request.
} 
we tabulate the yearly number of bankruptcies among firms that go public before 1996. In 1996, one percent of these newly public firms went bankrupt, and in 1997 this rate nearly doubled to 1.85 percent. In 1998, the rate doubled again to 3.97 percent.

To formally analyze the impact of the SEO market's collapse on newly public firms, we exploit differences in the timing of a firm's IPO to proxy for a firm's SEO demand after the collapse. A firm that goes public early, say in 1992 (hereafter the 'early' IPO firm), is likely to have already executed any planned SEOs by 1997 and is less likely to be affected by the equity market's collapse relative to a firm that goes public later, say in 1995 (hereafter the 'later' IPO firm). To estimate the effect of the equity market's collapse on the newly public firms, we test for post-1996 differences in the performance trend of the later IPO firms relative to the early IPO firms. Our approach will thus employ a difference-in-difference estimation, with an identifying assumption that, absent the equity market's collapse, the trend in the post-IPO performance of the later IPO firms should be similar to that of the early IPO firms.

To implement this difference-in-difference approach, we estimate a fixed effects model similar to Equation (2) that includes all firms that remain private or public during the sample period and all firms that go public between 1992 and $1996 .{ }^{29}$ However, we now make two changes. First, to reduce the number of estimated coefficients, without affecting the conclusions, we simplify the earlier model to include just an indicator for performance in the year of the IPO and three indicators for postIPO performance. Second, and most importantly, we allow for a change in post-IPO performance after 1996. This will be our test of whether the collapse of the public equity market affected the

\footnotetext{
${ }^{29}$ We exclude the firms that go public between 1996-2002. We do this to simplify our specification and reduce the number of control variables. Since the post-IPO performance of these firms is likely different from the pre-1997 IPOs, including them in the sample would require adding controls for their potentially different post-IPO performance. In unreported tests, we repeat the tests after including these firms and additional control variables and obtain results similar to the ones reported in Table VIII.
} 
performance of the later IPO firms. Specifically, we estimate the following model:

$$
y_{i t}=\left(\begin{array}{c}
\beta_{0}+\sum_{s=0}^{2} \Gamma_{s} \text { Post-IPO }(\mathrm{s})_{i t}+\Gamma_{3} \text { Post-IPO }(3+)_{i t} \\
+\gamma\left[\text { Post-IPO }(1+)_{i t} \times \text { Post- } 1996 t\right]+\alpha_{i}+\delta_{t}+\varepsilon_{i t}
\end{array}\right) \text {, }
$$

where Post-IPO(s) is an indicator that equals one if it is $s$ years since the IPO, Post-IPO $(s+)$ is an indicator that equals one if it is $s$ or more years since the IPO, and Post-1996 is an indicator equal to one for years after 1996. We include both firm and year fixed effects and cluster standard errors at the firm level.

To summarize, the first line of this equation estimates average changes in the performance of firms in the year of the IPO, one year after, two years after, and three or more years after the IPO relative to pre-IPO years and changes for all other firms. ${ }^{30}$ The second line of the equation tests for a post-1996 shift in the performance of firms that go public on or before 1996. This shift will be captured by $\gamma$. Since we directly control for the predicted path of firms' post-IPO performance and exclude firms that go public after 1996, $\gamma$ will be estimated only using variation in the timing of the pre-1997 IPOs. In other words, the coefficient will capture any shift in the post-IPO performance after 1996 of the later IPO firms relative to the post-IPO performance of early IPO firms. The results are reported in Table VIII.

The evidence indicates that the later IPO firms exhibit a significant decrease in their sales growth after the market's collapse in 1996 relative to the earlier IPO firms. In Column (1) of Panel A, we just include the indicators for post-IPO performance for comparison with our earlier results. Consistent with the results in Figure 1, we see that sales increases at a faster rate for IPO firms beginning one year after the IPO and continues to increase for up to three years after the IPO, at which time it levels off at the higher level. In Column (2), we allow the post-IPO performance to

\footnotetext{
${ }^{30}$ This estimation is similar to that of Equation (2), but with fewer indicator variables. We do this to reduce the number of parameters to be estimated.
} 
vary after 1996 by including Post-IPO(1+)×Post-1996 in the regression. The negative co-efficient on Post-IPO $(1+) \times$ Post-1996 indicates a significant drop in sales after 1996 for the later IPO firms. The drop is also economically large in magnitude. The later IPO firms experience a 9.5 percentage points slower sales growth rate after 1996 as compared to the early IPO firms.

To illustrate these results further, in Figure 3 we plot the implied post-IPO changes in $\log ($ Sales) for firms that go public in 1992 and 1995. The 1992 IPO line plots the estimated values of $\Gamma_{0}, \Gamma_{1}$, $\Gamma_{2}$, and $\Gamma_{3}$ from Equation (4) (see Column (2) of Table VIII), and represents the post-IPO change in $\log ($ Sales) for a firm that goes public in 1992. The 1995 IPO line, plots the estimated path for a firm that goes public in 1995. The gap between the two lines is a measure of the change in post-IPO performance of a 1995 IPO after the market's collapse relative to a 1992 IPO. This shift is captured by the coefficient $\gamma$ from Table VIII, Column (2).

Beyond experiencing slower sales growth following the equity market's collapse, the later IPO firms also exhibit elevated post-IPO debt levels, reduced profitability, and increased bankruptcy rates relative to early IPO firms. The increased leverage [Table VIII, Panel A, Column (4)] suggests that the later IPO firms rely more heavily on debt finance following the collapse of the SEO market. The increased use of debt, however, does not appear to provide a complete substitute for equity finance. The post-IPO profitability of the later IPO firms is lower following the market's collapse [Table VIII, Panel B, Column (2)], and bankruptcy rates are 4.5 percentage points higher [Column (4)]. Together, these indicate that the later IPO firms are adversely affected by the market's collapse. 


\section{Robustness Checks and Additional Tests}

To summarize, the investment and performance of both private and public firms more likely to rely on external equity finance decline relative to their public and private counterparts after the equity market's collapse. Private firms that resemble pre-1997 IPO firms exhibit large drops in capital expenditures and profitability relative to other private firms after 1996. Public firms that resemble pre-1997 SEO firms, non-group firms and firms that go public just before the equity market's collapse also experience large drops in performance relative to other public firms. The timing of the observed changes also coincide with the equity market collapse.

The identifying assumption behind our difference-in-difference estimates is that, absent the market's collapse, the performance trend of the firms more dependent on external equity finance will be similar to that of the firms less dependent on external equity finance. The firm fixed effects control for time-invariant differences across firms, and the time fixed effects control for country-level shifts in investment and growth.

This assumption could be violated, however, if some factor unrelated to the equity market, such as a new technology or change in consumer demand, disproportionately affects the performance of equity dependent firms. In this case, the equity market collapse may actually be in anticipation of the future negative shocks to those firms' investment opportunities.

While it is not possible to fully exclude such a possibility, we have three pieces of evidence that go against this explanation. First, the shear magnitude and suddenness of the drop in the number of equity issues from 1996 to 1997 goes against the alternate explanation of learning about diminished investment opportunities. Such changes in investment opportunities and the market's awareness about the changes are likely to occur more gradually. Second, as noted, both overall GDP and bank credit continued to grow strongly after 1996. Overall GDP averaged six percent 
annual growth both prior to the equity market's collapse, 1993 to 1996, and afterwards, 1997 to 2000, and outstanding bank credit grew at an average annual rate of 16.6 percent from 1993 to 1996 and 16.4 percent from 1997 to 2000 . This makes it unlikely that investment opportunities would suddenly disappear for such a large sector of the economy especially among firms more likely to rely on outside equity finance. Third, our evidence indicates that at least some of the equity dependent firms increase their use of debt following the equity market's collapse, highlighting their need to finance investment opportunities.

Our evidence pertaining to newly public firms in Section 4.4, however, could be consistent with yet another explanation. Since our estimates are obtained by comparing the post-IPO performance of firms that went public immediately prior to the equity market's collapse to the post-IPO performance of firms that went public in earlier years, one possible explanation for this particular result is that the later IPO firms are of poor quality as compared to the early ones. For example, the later IPO firms could consist of more 'fly-by-night' operators that took advantage of investor optimism and defrauded investors.

We perform two additional tests to help rule out this alternative explanation. First, we repeat our analysis in Table VIII using only IPO firms with more than two years of pre-IPO financial data and with older firms incorporated prior to 1991. Our results are similar in these subsamples which strongly suggests that the post-collapse decline in performance is not driven by the unraveling of 'fly-by-night' firms as these firms are unlikely to have more than two years of pre-IPO financial data or be incorporated prior to 1991. Second, we repeat our estimates of (4) for $\log ($ Sales) after further dividing the sample of firms based on external finance needs, asset tangibility, and group-affiliation. If the inability to raise outside finance contributed to the post-1996 shift in performance of the later IPO firms, then we should expect the effects to be stronger for firms with more external finance needs, firms with fewer tangible assets to pledge as collateral for debt, and non-group firms that 
do not have access to a group's internal capital market. The alternative explanations do not have similar predictions. ${ }^{31}$

Consistent with the equity market collapse adversely affecting equity-dependent newly public firms, the estimates reported in Table IX indicate that the post-1996 decline in sales is stronger among later IPO firms with greater external finance needs. In Table IX, Column (1), we report the earlier estimation using the entire sample [see Table VIII, Column (2)]. In Table IX, Column (2), we repeat this earlier estimation but restrict our sample to firms in the bottom third of the $R-Z$ Index, and in Column (3), we only include firms in the top third. The estimates indicate that the post-1996 decline in sales among later IPO firms is primarily driven by firms with greater external finance needs. As seen in Column (3), later IPO firms with greater external finance needs had, on average, $12 \%$ lower sales growth in the post-IPO period as compared to earlier IPO firms that also had greater external finance needs. In comparison, the growth rate of later IPO firms with less external finance needs is not significantly different from that of earlier IPO firms with less external finance needs [Column (2)].

In Columns (4) and (5), we repeat the analysis after dividing the firms based on the tangibility of their assets. Again, we find that the post-1996 decline in sales is larger, on average, among the later IPO firms with fewer tangible assets. In Columns (6) and (7), we find that the drop is sales for the later IPO firms occurs primarily among non-group firms. While the estimates are noisy and the differences are not statistically significant at conventional levels (see row titled $\triangle$ Post-IPO $(1+) \times$ Post-1996), they are suggestive that the decline in post-IPO performance for the later IPO firms is driven in part by the equity market's collapse and the inability to raise follow-on finance.

Overall, these additional tests suggest that the adverse performance of firms following the equity market's collapse in 1996 is not just the "unravelling" of the 'fly-by-night' that went public prior

\footnotetext{
${ }^{31}$ These additional tests are reported in the paper's online appendix.
} 
to 1996 or the exclusion of new 'fly-by-night' firms from going public after 1996. Even firms with established track records but otherwise similar characteristics to firms issuing equity prior to the collapse decrease investment and growth following the collapse, and this is particularly true among firms with greater dependence on external financing. Moreover, while there were certainly some 'bad apples' in India's hot IPO market of 1992-1996, many of the firms going public during this period went on to be quite successful. Of the 1,094 firms that went public between 1992 and 1996 and are captured in our data, at least 673 were still operating 10 years later in 2006, and accounted for over 11 percent of total sales in their respective industries.

\section{Concluding Remarks}

Are public equity markets important for a firm's growth and investments in emerging economies? Answering this question is difficult because any observed correlation between stock price changes and a firm's investments may be due to a shift in investment opportunities rather than a change in a firm's access to equity finance. Using detailed firm-level data on both private and public firms, we circumvent this problem by analyzing the sudden collapse of India's equity market in 1997, which was driven by a shift in regulations and investor confidence largely unrelated to firms' investment opportunities. Following the equity market's collapse, small, young firms' ability to issue equity appears to decrease significantly, and only larger, older firms with greater investment opportunities and past capital expenditures successfully issue equity. This shift in market structure suggests that post-1996 the public equity markets were available as a financing option only for the less risky and more established firms.

Similar to banking crises, an equity market collapse appears to have important implications for the growth and investment of firms. Our findings suggest that both public and private firms in India were adversely affected by the collapse of the equity market, but some firms appeared 
particularly sensitive to the absence of a strong IPO and SEO market. We find that newly public firms, non-group firms, young firms, firms with few intangible assets, and firms with greater needs for external finance exhibit larger average drops in growth, investment, and profitability following the equity market's collapse.

Overall, the evidence regarding firms' performance following India's equity market's collapse in 1997 suggests that public equity markets have the potential to expand access to finance and foster greater investment in emerging economies. Our findings also suggest that the public equity markets may be an important source of finance in emerging economies, and for many firms, they are not always easily replaced by alternate sources of finance. Regulations and institutions that facilitate equity financing for small, young firms, such as the AIMs exchange in London, may play a unique and important role in the growth of these firms.

These findings raise an important question; why do some firms appear to be more 'equity dependent' than others? While there is a large empirical literature exploring the 'uniqueness' of banks and the existence of 'bank-dependent' firms, there is relatively little evidence as to what makes some firms more equity dependent despite many theories that highlight the costs of debt and bank finance (e.g., Rajan, 1992, and Rajan and Zingales, 2003). Our evidence shows that equity markets may be a particularly attractive source of finance for small, young, non-group firms in emerging markets. Exploring what makes equity markets 'unique' in providing finance for such firms is an area ripe for investigation. 


\section{REFERENCES}

Aslan, H. and Kumar, P. (2011) Lemons or cherries? Growth opportunities and market temptations in going public and private, Journal of Financial and Quantitative Analysis, 46(2), 489-526.

Baker, M., Stein, J. and Wurgler, J. (2003) When does the market matter? Stock prices and the investment of equity dependent firms, Quarterly Journal of Economics 118, 969-1006.

Beck, T., Demirguc-Kunt, A. and Maksimovic, V. (2005) Financial and legal constraints to firm growth: Does firm size matter?, Journal of Finance 60, 137-177.

Beck, T. and Levine, R. (2002) Industry growth and capital allocation: Does having a market- or bank-based system matter? Journal of Financial Economics 64, 147-180.

Bekaert, G., Harvey, C. and Lundblad, C. (2005) Does financial liberalization spur growth?, Journal of Financial Economics 77, 3-55.

Bharath, S. and Dittmar, A. (2010) Why do firms use private equity to opt out of public markets?, Review of Financial Studies 23(5), 1772-1818.

Black, B. and Gilson, R. (1998) Venture capital and the structure of capital markets: Banks versus stock markets, Journal of Financial Economics 43, 243-277.

Boehmer, E. and Ljungqvist, A. (2004) On the decision to go public: Evidence from privately-held firms, unpublished working paper, EDHEC Business School and New York University, Available at SSRN: http://ssrn.com/abstract=266993.

Borensztein, E. and Lee, J-W. (2002) Financial crisis and credit crunch in Korea: Evidence from firm-level data, Journal of Monetary Economics 49(4), 853-75.

Bubna, A. and Prabhala, N. (2007) When bookbuilding meets IPOs, Indian School of Business and University of Maryland, Working Paper Available at SSRN: http://ssrn.com/abstract=972757.

Chemmanur, T., He, S. and Nandy, D. (2010) The Going public decision and the product market, Review of Financial Studies, 23(5), 1855-1908.

Demirguc-Kunt, A. and Levine, R. (2001) Financial structure and economic growth: A cross-country comparison of banks, markets, and development, MIT Press Cambridge, MA.

Eckbo, E. and Masulis, R. (1995). Seasoned equity offerings: A survey. In Jarrow, R.A., Ziemba, V.M.W.T. (eds.), Finance, Handbooks in Operation Research and Management Science, Vol. 9, North-Holland, Amsterdam, pp. 1017-1072, (Chapter 31).

Fischer, C. (2000) Why do companies go public? Empirical evidence from Germany's Neuer market, unpublished working paper, Munich School of Management, Available at SSRN:

http://ssrn.com/abstract=229529 or DOI: 10.2139/ssrn.229529. 
Gopalan, R., Nanda, V. and Seru, A. (2007) Affiliated firms and financial support: Evidence from Indian business groups, Journal of Financial Economics 86(3), 759-795.

Gormley, T., Johnson, S. and Rhee, C. (2011) Ending 'Too Big to Fail': Government Promises vs. Investor Perceptions, unpublished working paper, University of Pennsylvania, Massachusetts Institute of Technology, and Asian Development Bank, Available at SSRN: http://ssrn.com/abstract=1364891.

Henry, P.B. (2000a) Stock market liberalization, economic reform, and emerging market equity prices, Journal of Finance 55, 529-564.

Henry, P.B. (2000b) Do stock market liberalizations cause investment booms? Journal of Financial Economics 58, 301-334.

Keynes, J.M. (1936) The General Theory of Employment, Interest, and Money (London: Macmillan).

Khwaja, A. and Mian, A. (2005) Do lenders favor politically connected firms? Rent provision in an emerging financial market, Quarterly Journal of Economics 120, 1371-1411.

Khwaja, A. and Mian, A. (2008) Tracing the impact of bank liquidity shocks, American Economic Review 98, 14131442. .

Kim, W. and Weisbach, M. (2008) Motivations for public equity offers: An international perspective, Journal of Financial Economics 87, 281-307.

La Porta, R., Lopez-de-Silanes, F. and Shleifer, A. (2002) Government ownership of banks, Journal of Finance 57, 265-301.

Marisetty, V.B. and Subrahmanyam, M.G. (2010) Group Affiliation and the Performance of Initial Public Offerings in the Indian Stock Market, Journal of Financial Markets 13, 196-223.

Morck, R. and Nakkamura, M. (1999). Banks and corporate control in Japan, Journal of Finance 54, 319-340.

Morck, R., Shleifer, A. and Vishny, R. (1990) The Stock Market and Investment: Is the Market a Sideshow? Brookings Papers on Economic Activity 2, 157215.

Ongena, S., Smith, D. and Michalsen, D. (2003) Firms and their distressed banks: Lessons from the Norwegian banking crisis, Journal of Financial Economics 67, 81-112.

Pagano, M., Panetta, F. and Zingales, L. (1998) Why do companies go public? An empirical analysis, Journal of Finance 53, 27-64.

Paravisini, D. (2008) Local bank financial constraints and firm access to external finance, Journal of Finance, 63(5), 2161-2193.

Rajan, R. (1992) Insiders and outsiders: The choice between informed and arm's-length debt, Journal of Finance 47, 1367-1400. 
Rajan, R. and Zingales, L. (1998) Financial dependence and growth, American Economic Review 88, 559-586.

Rajan, R. and Zingales, L. (2003) The great reversals: The politics of financial development in the 20th century, Journal of Financial Economics 69, 5-50.

Securities and Exchange Board of India. (1997) Annual Report 1996-97.

Securities and Exchange Board of India. (1998) Annual Report 1997-98.

Securities and Exchange Board of India. (2006) Handbook of Statistics on the Indian Security Markets. 
CAPEX
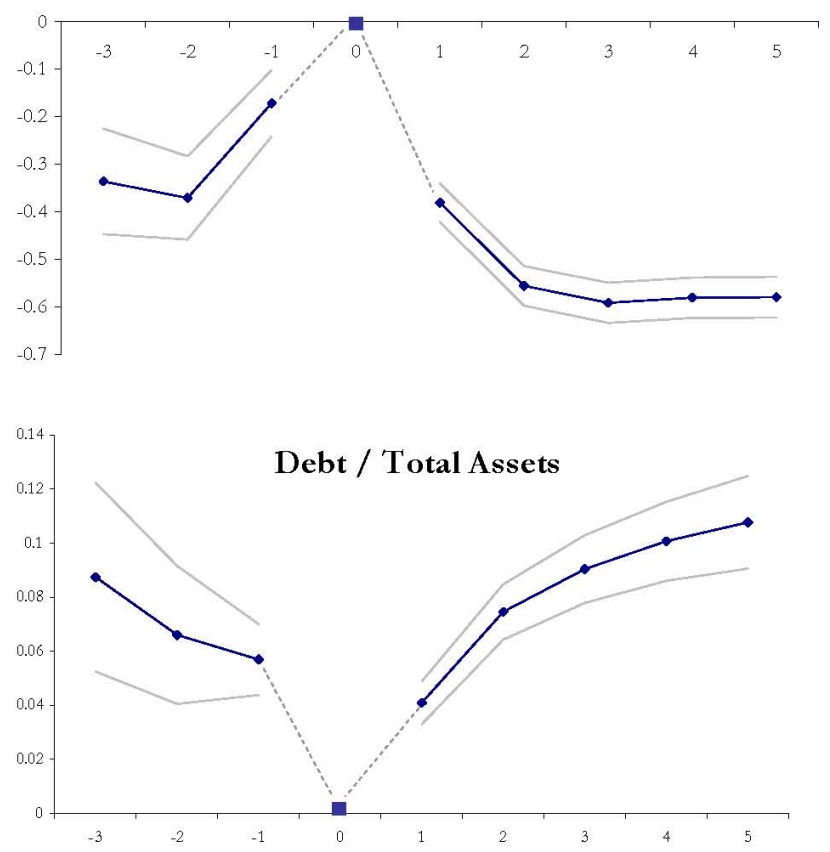
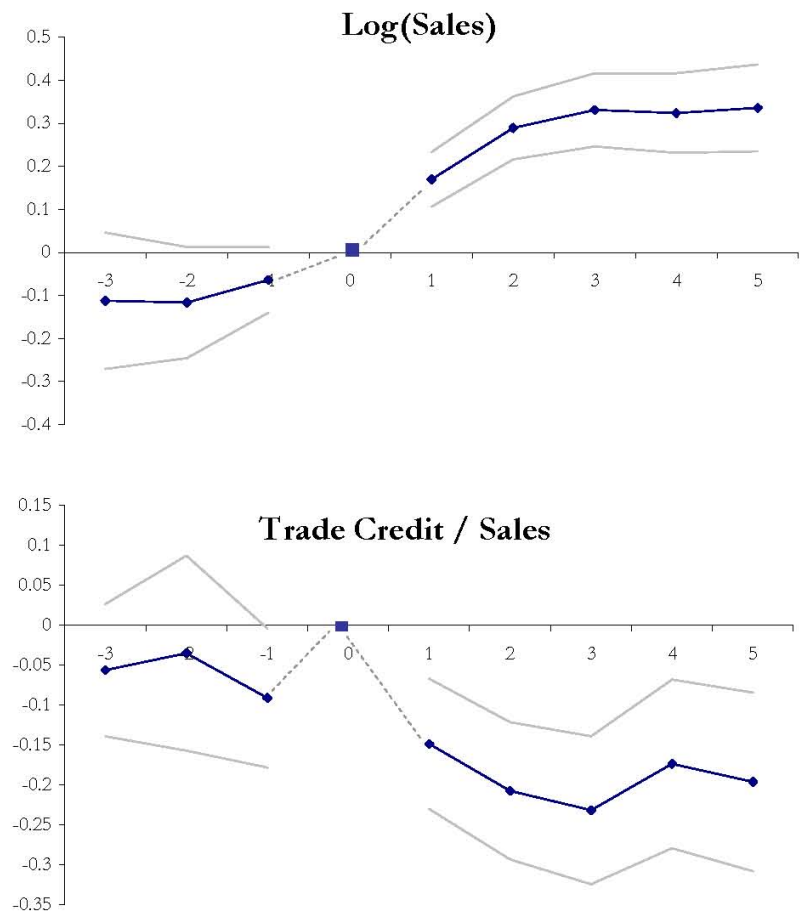

\section{Figure 1: Post-IPO Performance}

Each figures plots the point estimates from a separate OLS regression with interaction terms for each year relative to the year a firm goes public, with the year of the IPO being the excluded category (year $=0$ ). While the model was fully saturated, only point estimates for three years prior and five years after the IPO are reported. The regression also included both year and firm fixed effects. The four dependent variables used are: Log(Sales), Capital Expenditure, Debt/TA, and Trade Credit/Sales. The IPO data is from SDC while the financial data is from the Prowess database. The sample includes all non-Government and non-foreign firms from Prowess for the years 1992-2002. The standard errors are clustered at the firm level, and gray lines represent the 95 percentile confidence intervals. 


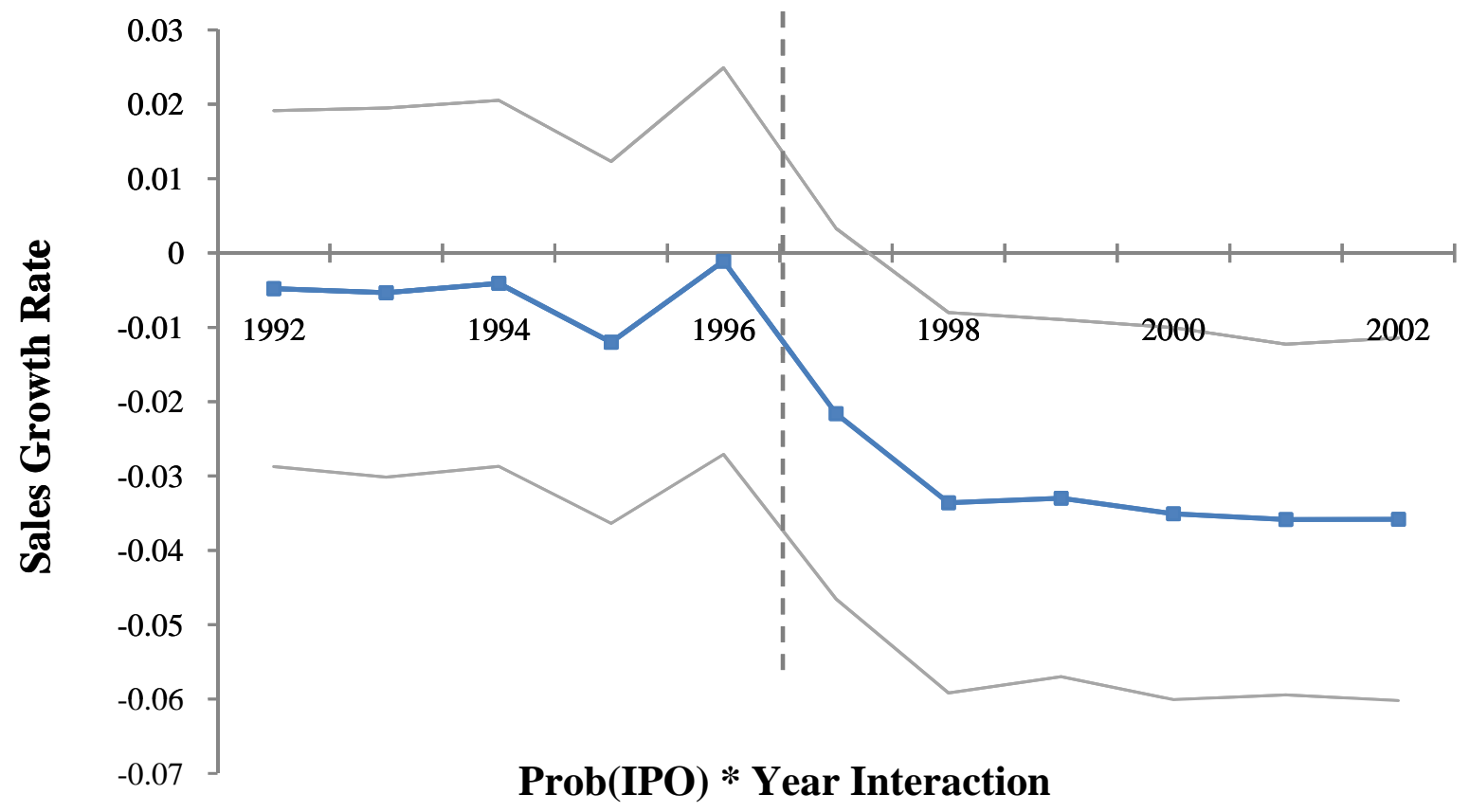

Figure 2: IPO Market Collapse and Private Firms' Sales Growth by Year

This figure reports the point estimates of a panel regression that investigates the differential change in sales growth after the equity market's collapse for private firms that are more likely to benefit from a strong IPO market relative to private firms that are less likely to rely on equity-financing. This specification is the same as that reported in Table V, Panel A, Column (2) except that the effect of Prob(IPO) is now allowed to vary by year. Ninety-five percent confidence intervals, adjusted for clustering at the firm level, are also plotted. 


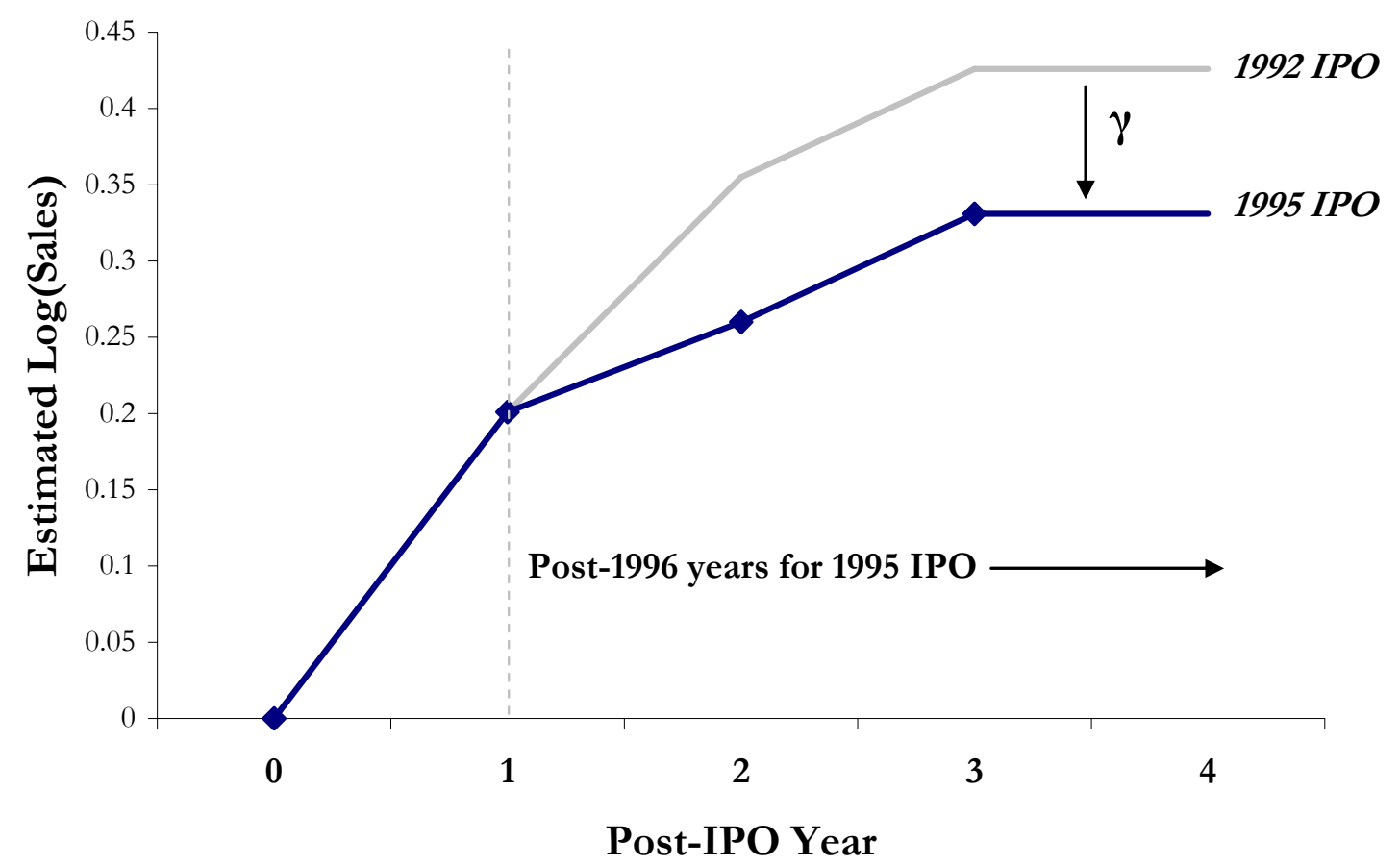

Figure 3: Estimating the Impact of the Equity Market Collapse on Newly Public Firms

This figure illustrates the underlying idea behind the estimation of equation (4), where we attempt to identify the impact of the public equity market's collapse on newly public firms. The figure plots the point estimates from the estimation of equation (4) when we use $\log ($ Sales) as the dependent variable. The 1992 IPO line represents estimated post-IPO change in $\log$ (Sales) for a firm that goes public in 1992 relative to that of all other firms. In equation (4), this estimated change is captured by $\Gamma_{0}, \Gamma_{1}, \Gamma_{2}$, and $\Gamma_{3}$, which are reported in Column (2) of Table XIII. Similar to our earlier results, we find an increase in $\log$ (Sales) beginning one year after going public that begins to level off at a higher level three years after going public. In the 1995 IPO line, we plot the estimated path for a firm that goes public three years later in 1995. In estimating equation (4), the post-IPO performance of the 1995 IPO is allowed to vary from that of earlier IPOs after the equity markets collapse in late 1996. This potential shift in post-IPO performance relative to the post-IPO performance of earlier IPOs is captured by the coefficient, $\gamma$. The negative estimate for $\gamma$ found in Table XIII, Column (2), indicates a drop in the $\log$ (Sales) of the later IPOs after 1996 relative to what we observed among firms that went public earlier. 


\section{Table I: Sample Distribution}

This table reports the year-wise distribution of public firms, private firms, IPOs, and SEOs in our sample. Column (1) provides the number of all firms, while Columns (2)-(3) break down the sample between public and private firms. Columns (4) and (5) provide the number of IPOs and SEOs respectively.

Sample Distribution

\begin{tabular}{r|rrrrr}
\hline & Full Sample & Public Firms & Private Firms & IPOs & SEOs \\
\hline 1992 & 1,955 & 1,333 & 622 & 62 & 20 \\
1993 & 2,468 & 1,612 & 856 & 137 & 44 \\
1994 & 3,201 & 2,078 & 1,123 & 343 & 59 \\
1995 & 3,988 & 2,815 & 1,173 & 393 & 63 \\
1996 & 4,361 & 3,375 & 986 & 159 & 23 \\
1997 & 4,396 & 3,480 & 916 & 6 & 6 \\
1998 & 4,406 & 3,344 & 1,062 & 4 & 1 \\
1999 & 4,646 & 3,340 & 1,306 & 9 & 0 \\
2000 & 4,873 & 3,346 & 1,527 & 56 & 1 \\
2001 & 4,158 & 2,904 & 1,254 & 6 & 4 \\
2002 & 2,537 & 1,850 & 687 & 0 & 10 \\
\hline Total & 40,989 & 29,477 & 11,512 & 1,175 & 231 \\
\hline
\end{tabular}

\section{Table II: Descriptive Statistics}

This table reports descriptive statistics for our sample of firms. The first column reports averages for the entire sample while the second and third columns report averages for public and private firms only. The standard deviations are reported in parentheses. Total Assets is the book value of total assets in units of Rs. 10 million. Age is the number of years since incorporation. Group is a dummy variable that takes a value 1 for firms that belong to a business group. CapEx/TA is the ratio of the investment in property plant and equipment to the book value of gross fixed assets. $E B I T D A / T A$ is the ratio of earnings before interest depreciation taxes and amortization to total assets. Debt/TA is the ratio of book value of total borrowing to the book value of total assets. The sample includes all non-Government and non-foreign firms with assets greater than Rs. 50 million from Prowess for the years 1992-2002.

\begin{tabular}{l|r|r|r}
\hline & All Firms & Public Firms & Private Firms \\
\hline Total Assets (TA) & 445.6 & 588.13 & 80.66 \\
& $(4,245)$ & $(4,996)$ & $(297.7)$ \\
Age & 21.2 & 21.5 & 20.6 \\
& $(20.6)$ & $(20.5)$ & $(20.6)$ \\
Group & 0.423 & 0.400 & 0.481 \\
& $(0.494)$ & $(0.490)$ & $(0.500)$ \\
CaPex/TA & 0.185 & 0.161 & 0.259 \\
& $(0.364)$ & $(0.319)$ & $(0.467)$ \\
EBITDA/TA & 0.104 & 0.102 & 0.110 \\
Debt/TA & $(0.110)$ & $(0.109)$ & $(0.114)$ \\
& 0.389 & 0.398 & 0.365 \\
& $(0.315)$ & $(0.321)$ & $(0.298)$ \\
\hline Number of Observations & 40,989 & 29,477 & 11,512 \\
\hline \hline
\end{tabular}




\section{Table III: Who Goes Public?}

This table reports the results of regressions investigating which firms go public. Specifically, we estimate the panel regression: $y_{i t}=\beta_{0}+\beta_{1} X_{i t}+\gamma$ Controls + Year Fixed Effects, where $y$ is a dummy variable that takes a value 1 in the year in which a firm goes public and 0 otherwise. $X$ is a vector of firm characteristics. Sales is the total sales in units of Rs. 10 million. Age is the number of years since incorporation. EBIDTA/TA is the ratio of earnings before interest depreciation taxes and amortization to total assets. Group is a dummy variable that takes a value 1 for firms that belong to a business group. Industry Investment is the median investment by all firms in an industry, where investment is capital expenditures scaled by total assets. Industry Market-to-Book is the median ratio of market value of total assets to book value of total assets of all firms in an industry. RZ-Index is a measure of the external-finance dependence of a firm. It is measured using the methodology of Rajan and Zingales (1998). The IPO data is from SDC while the financial data is from the Prowess database. The sample includes all non-Government and non-foreign private firms with assets greater than Rs. 50 million from Prowess for the years 1992-2002. Columns (1)-(3) report OLS estimates, Column (4) reports estimates from a Logit model, and Column (5) reports estimates from a Cox proportional hazard model. The standard errors are clustered at the firm level. ***, **, and * indicate statistical significance at the $1 \%, 5 \%$, and $10 \%$ level.

\begin{tabular}{|c|c|c|c|c|c|}
\hline & \multicolumn{3}{|c|}{ OLS } & \multirow{2}{*}{$\begin{array}{c}\text { Logit } \\
(4)\end{array}$} & \multirow{2}{*}{$\begin{array}{c}\text { Hazard } \\
(5)\end{array}$} \\
\hline & (1) & $(2)$ & (3) & & \\
\hline$\overline{\log (\text { Sales })_{t-1}}$ & $\begin{array}{c}-.012^{* * *} \\
(.002)\end{array}$ & $\begin{array}{c}-.013^{* * *} \\
(.002)\end{array}$ & $\begin{array}{c}-.018^{* * *} \\
(.002)\end{array}$ & $\begin{array}{c}-.136^{* * *} \\
(.030)\end{array}$ & $\begin{array}{l}-.016 \\
(.016)\end{array}$ \\
\hline $\log (\text { Age })_{t}$ & $\begin{array}{c}-.059^{* * *} \\
(.003)\end{array}$ & $\begin{array}{c}-.064^{* * *} \\
(.003)\end{array}$ & $\begin{array}{c}-.067^{* * *} \\
(.004)\end{array}$ & $\begin{array}{c}-.913^{* * *} \\
(.056)\end{array}$ & $\begin{array}{c}-.366^{* * *} \\
(.032)\end{array}$ \\
\hline $\mathrm{EBIDTA} / \mathrm{TA}_{t-1}$ & $\begin{array}{c}.073^{* * *} \\
(.022)\end{array}$ & $\begin{array}{c}.084^{* * *} \\
(.022)\end{array}$ & $\begin{array}{c}.118^{* * *} \\
(.026)\end{array}$ & $\begin{array}{c}1.692^{* * *} \\
(.435)\end{array}$ & $\begin{array}{c}.942^{* * *} \\
(.256)\end{array}$ \\
\hline Industry Debt/TA $t$ & $\begin{array}{c}-.064^{* * *} \\
(.023)\end{array}$ & $\begin{array}{c}-.098^{* * *} \\
(.024)\end{array}$ & $\begin{array}{c}-.173^{* * *} \\
(.034)\end{array}$ & $\begin{array}{c}-2.390^{* * *} \\
(.427)\end{array}$ & $\begin{array}{c}-.956^{* * *} \\
(.228)\end{array}$ \\
\hline Group & $\begin{array}{c}-.084^{* * *} \\
(.005)\end{array}$ & $\begin{array}{c}-.088^{* * *} \\
(.005)\end{array}$ & $\begin{array}{c}-.080^{* * *} \\
(.006)\end{array}$ & $\begin{array}{c}-1.284^{* * *} \\
(.103)\end{array}$ & $\begin{array}{c}-.705^{* * *} \\
(.072)\end{array}$ \\
\hline Industry Investment $_{t}$ & $\begin{array}{c}.540^{* * *} \\
(.056)\end{array}$ & & & $\begin{array}{c}1.641^{* * *} \\
(.405)\end{array}$ & $\begin{array}{c}.500^{* * *} \\
(.175)\end{array}$ \\
\hline Industry Market-to-Book $t$ & & $\begin{array}{c}.067^{* * *} \\
(.014)\end{array}$ & & & \\
\hline RZ-Index & & & $\begin{array}{c}.024^{* * *} \\
(.009)\end{array}$ & & \\
\hline Year Fixed Effects & $\mathrm{X}$ & $\mathrm{X}$ & $\mathrm{X}$ & $\mathrm{X}$ & $\mathrm{X}$ \\
\hline Obs. & 8932 & 8896 & 7000 & 8290 & 8932 \\
\hline$R^{2}$ of Pseudo $R^{2}$ & .295 & .282 & .268 & .414 & .083 \\
\hline
\end{tabular}




\section{Table IV: Going Public Decision - Pre and Post 1996}

This table reports the results of regressions investigating how the going public decision varies across the pre- and post-1996 period. Specifically, in Column (1), we estimate the OLS regression: $y_{i t}=\beta_{0}+\beta_{1} X_{i t}+\gamma$ Controls + Time $\mathrm{FE}$, where $y$ is a dummy variable that takes a value 1 in the year in which a firm goes public and 0 otherwise. $X$ is a vector of firm characteristics that include $\log ($ Sales), $\log ($ Age ), EBITDA/TA, Industry Debt, Industry Investment, and Group. In Column (2), we add interaction terms between Post-1996 IPO, a dummy variable that takes a value 1 for firms that go public after 1996, and $\log ($ Sales), Log(Age), and Industry Investment. The IPO data is from SDC while the financial data is from the Prowess database. The sample includes all non-Government and non-foreign private firms from Prowess for the years 1992-2002. Columns (1)-(2) report OLS estimates, Column (3) reports estimates from a Logit model, and Column (4) reports estimates from a Cox proportional hazard model. Standard errors are clustered at the firm level. ***,**, and * indicate statistical significance at the 1\%, $5 \%$, and $10 \%$ level.

\begin{tabular}{|c|c|c|c|c|}
\hline & \multicolumn{2}{|c|}{ OLS } & \multirow{2}{*}{$\frac{\text { Logit }}{(3)}$} & \multirow{2}{*}{$\begin{array}{c}\text { Hazard } \\
(4)\end{array}$} \\
\hline & (1) & $(2)$ & & \\
\hline $\log (\text { Sales })_{t-1}$ & $\begin{array}{c}-.012^{* * *} \\
(.002)\end{array}$ & $\begin{array}{c}-.013^{* * *} \\
(.001)\end{array}$ & $\begin{array}{c}-.191^{* * *} \\
(.033)\end{array}$ & $\begin{array}{c}-.049^{* * *} \\
(.017)\end{array}$ \\
\hline $\log (\text { Age })_{t}$ & $\begin{array}{c}-.059^{* * *} \\
(.003)\end{array}$ & $\begin{array}{c}-.055^{* * *} \\
(.003)\end{array}$ & $\begin{array}{c}-.880^{* * *} \\
(.060)\end{array}$ & $\begin{array}{c}-.385^{* * *} \\
(.034)\end{array}$ \\
\hline $\mathrm{EBIDTA} / \mathrm{TA}_{t-1}$ & $\begin{array}{c}.073^{* * *} \\
(.022)\end{array}$ & $\begin{array}{c}.055^{* * *} \\
(.021)\end{array}$ & $\begin{array}{c}1.399^{* * *} \\
(.444)\end{array}$ & $\begin{array}{c}.887^{* * *} \\
(.255)\end{array}$ \\
\hline Industry Debt/TA $t$ & $\begin{array}{c}-.064^{* * *} \\
(.023)\end{array}$ & $\begin{array}{l}-.017 \\
(.022)\end{array}$ & $\begin{array}{c}-1.673^{* * *} \\
(.471)\end{array}$ & $\begin{array}{c}-.541^{* *} \\
(.234)\end{array}$ \\
\hline Industry Investment $_{t}$ & $\begin{array}{c}.540^{* * *} \\
(.056)\end{array}$ & $\begin{array}{c}.431^{\text {*** }} \\
(.056)\end{array}$ & $\begin{array}{l}.816^{* *} \\
(.411)\end{array}$ & $\begin{array}{c}.174 \\
(.181)\end{array}$ \\
\hline Group & $\begin{array}{c}-.084^{* * *} \\
(.005)\end{array}$ & $\begin{array}{c}-.079^{* * *} \\
(.005)\end{array}$ & $\begin{array}{c}-1.241^{* * *} \\
(.108)\end{array}$ & $\begin{array}{c}-.695^{* * *} \\
(.074)\end{array}$ \\
\hline Post $1996 \mathrm{IPO} \times \log (\text { Sales })_{t-1}$ & & $\begin{array}{l}-.006 \\
(.022)\end{array}$ & $\begin{array}{c}.218 \\
(.192)\end{array}$ & $\begin{array}{l}.167^{* *} \\
(.084)\end{array}$ \\
\hline Post $1996 \operatorname{IPO} \times \log (\text { Age })_{t}$ & & $\begin{array}{l}.108^{* *} \\
(.045)\end{array}$ & $\begin{array}{c}1.763^{* * *} \\
(.355)\end{array}$ & $\begin{array}{c}.660^{* * *} \\
(.180)\end{array}$ \\
\hline Post $1996 \mathrm{IPO} \times$ Industry Investment $_{t}$ & & $\begin{array}{c}1.090^{* * *} \\
(.260)\end{array}$ & $\begin{array}{c}5.177^{* *} \\
(2.368)\end{array}$ & $\begin{array}{c}2.454^{* * *} \\
(.880)\end{array}$ \\
\hline Year Fixed Effects & $\mathrm{X}$ & $\mathrm{X}$ & $\mathrm{X}$ & $\mathrm{X}$ \\
\hline Obs. & 8932 & 8932 & 8290 & 8932 \\
\hline$R^{2}$ or Pseudo $R^{2}$ & .295 & .318 & .46 & .093 \\
\hline
\end{tabular}




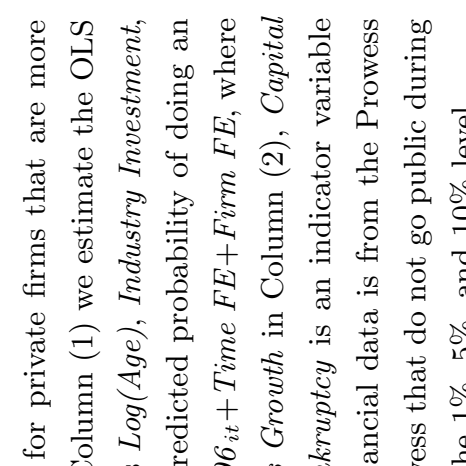

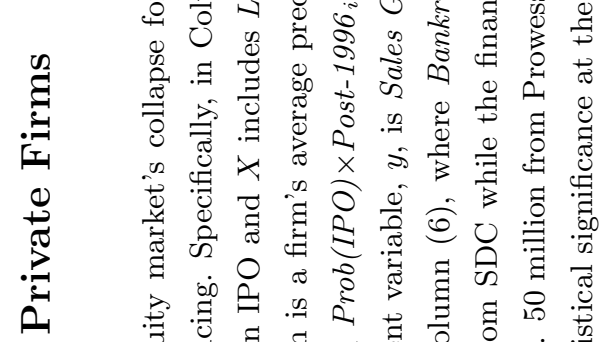

फ

O D

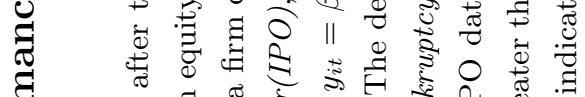

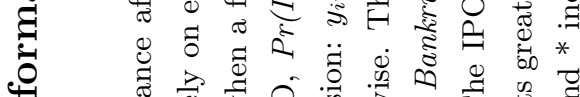

फ

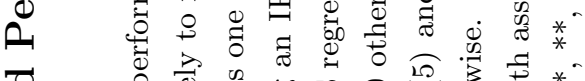

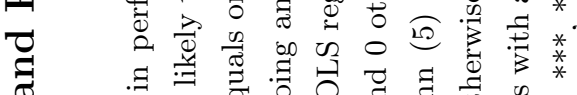

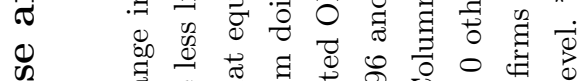

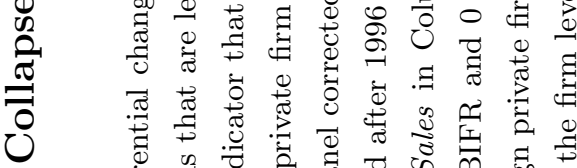

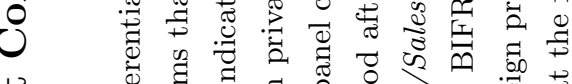

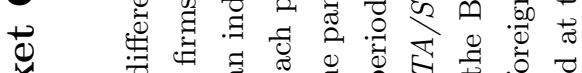

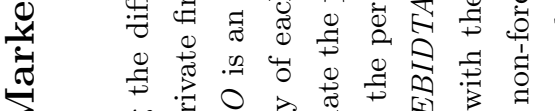

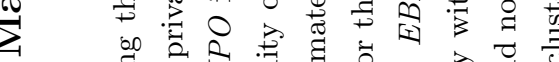

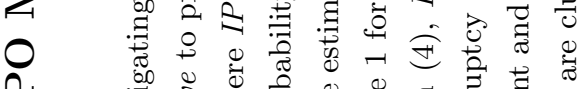

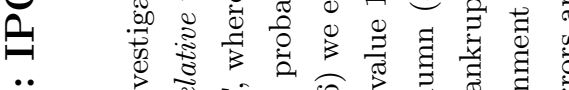

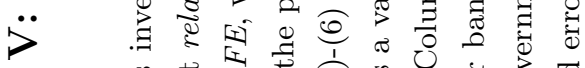

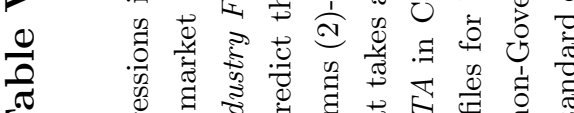

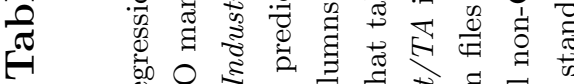

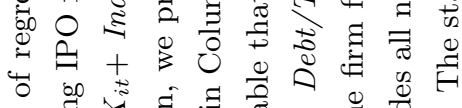

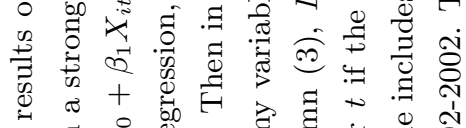
Ð

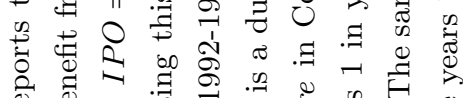

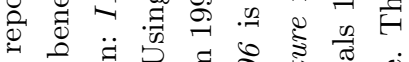

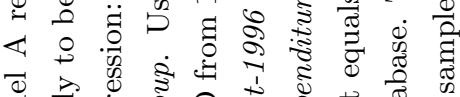

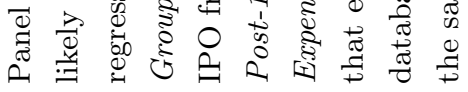

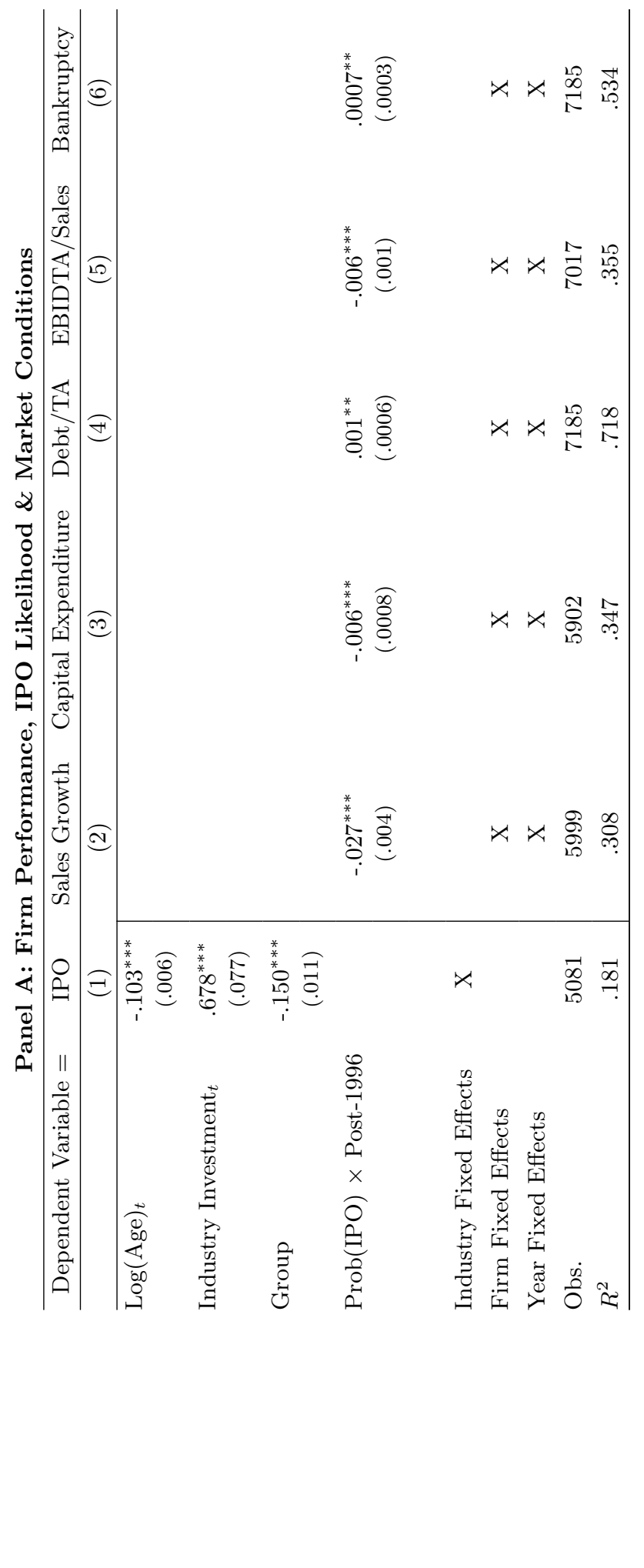




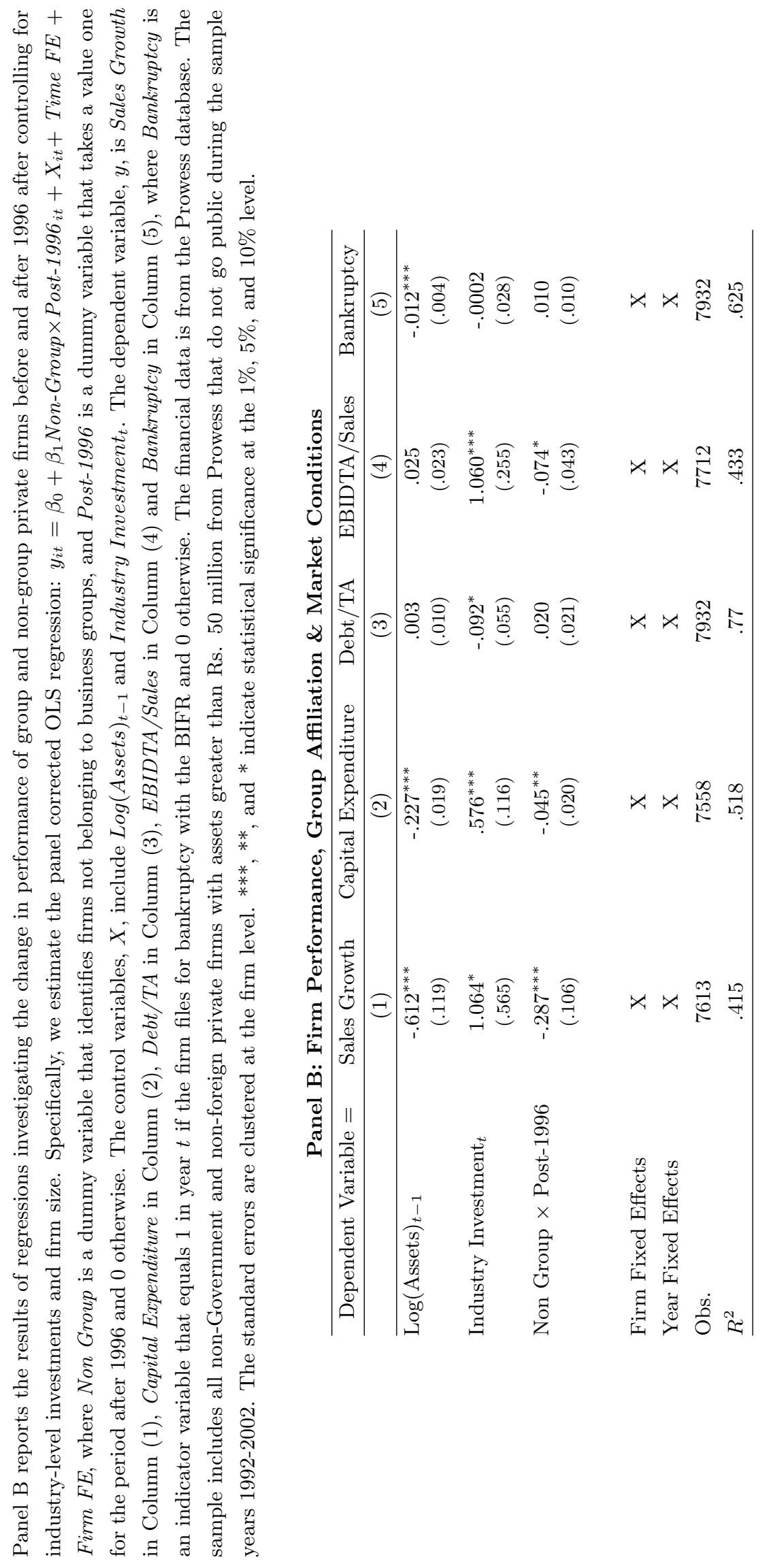




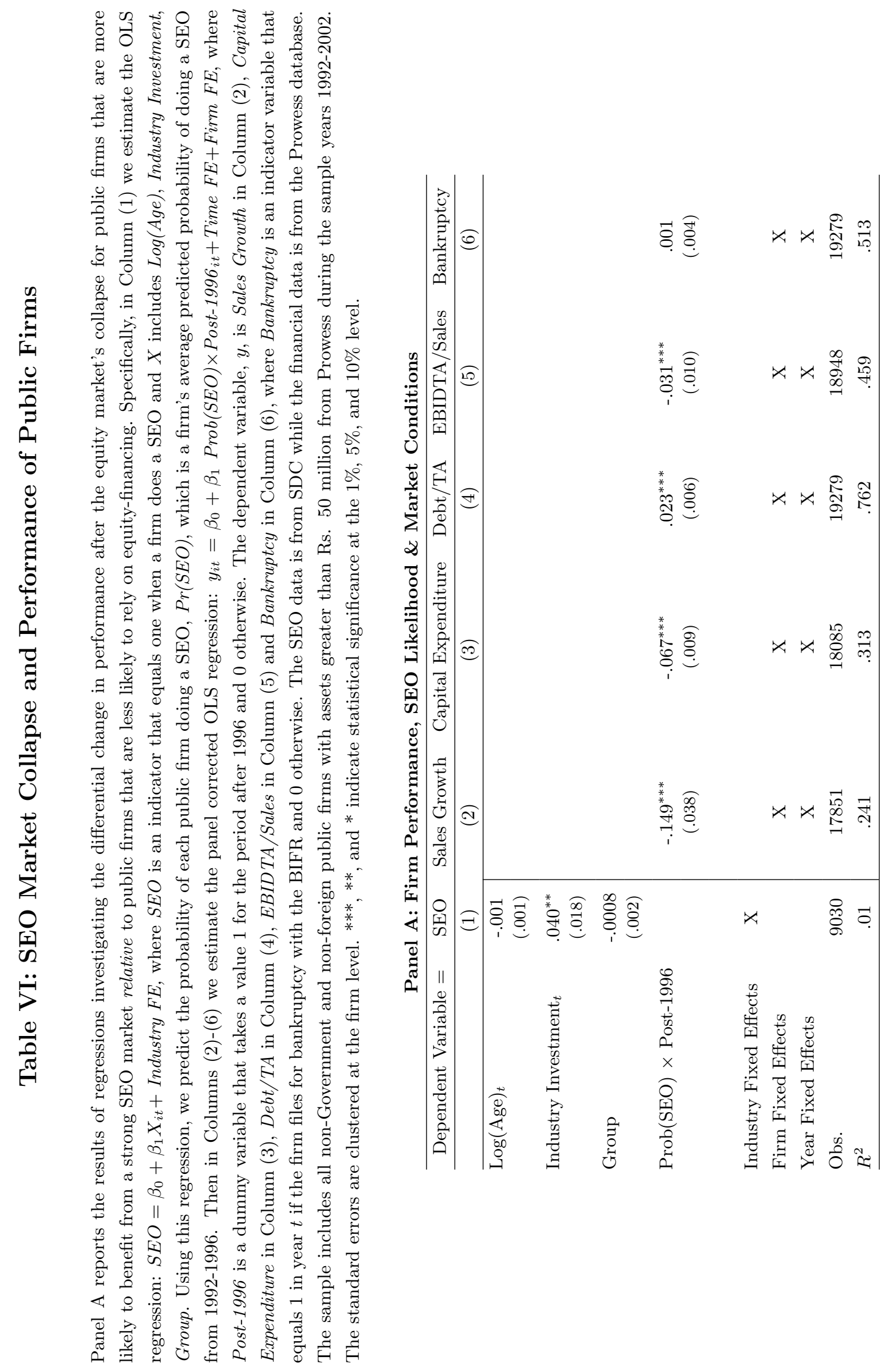




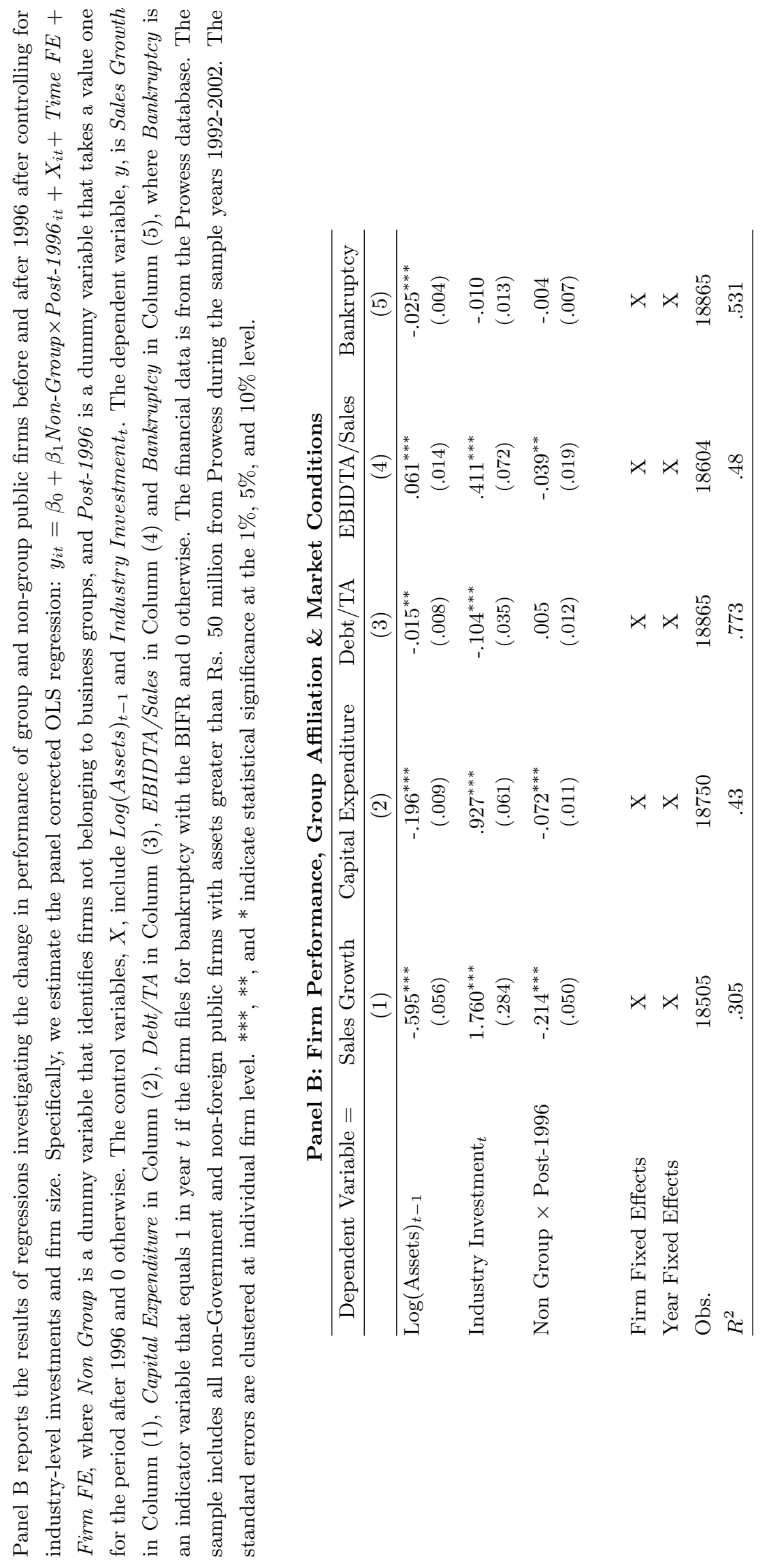




\section{Table VII: Bankruptcies Among Newly Public Firms}

This table reports the year-wise distribution of IPOs and firm bankruptcies among the newly public firms in our sample. The first column gives the total number of IPOs, the second column the number of newly public firms, the third column the number of bankruptcies among the newly public firms and the last column the fraction of newly public firms declaring bankruptcy of the subset of newly public firms found in the Prowess database. The IPO data is from SDC while the bankruptcy data is from India's Bureau of Industrial and Financial Reconstruction (BIFR). The sample includes all non-Government and non-foreign firms from Prowess for the years 1991-2002.

\begin{tabular}{|r|r|r|r|r|}
\hline Year & IPOS & Number of Newly Public Firms & Bankruptcies & \% Bankruptcies \\
\hline 1991 & 16 & 16 & 0 & 0 \\
1992 & 62 & 79 & 0 & 0 \\
1993 & 137 & 219 & 0 & 0 \\
1994 & 343 & 567 & 0 & 0 \\
1995 & 393 & 971 & 2 & 0.21 \\
1996 & 159 & 1,096 & 11 & 1.00 \\
1997 & 6 & 1,029 & 19 & 1.85 \\
1998 & 3 & 958 & 38 & 3.97 \\
1999 & 8 & 963 & 54 & 5.61 \\
2000 & 56 & 904 & 55 & 6.08 \\
2001 & 6 & 645 & 43 & 6.67 \\
2002 & 0 & 197 & 9 & 4.57 \\
\hline
\end{tabular}




\section{Table VIII: The Post-Collapse Performance of Newly Public Firms}

This table estimates the impact of the equity market's collapse on the post-IPO performance of newly public firms relative to the post-IPO performance of other public firms. Specifically, we estimate the following OLS regression with both firm fixed effects and year dummies: $y_{i t}=\beta_{0}+s u m_{s=0}^{2} \Gamma_{s} \operatorname{Post}-\mathrm{IPO}(\mathrm{s})_{i t}+\Gamma_{3}$ Post-IPO $(3+)_{i t}+\gamma\left[\mathrm{Post}-\mathrm{IPO}(1+)_{i t} \times\right.$ Post-1996t $]+\alpha_{i}+\delta_{t}+\varepsilon_{i t}$ where Post-IPO $(s)$ is an indicator that equals one if it is $s$ years since the firm went public, Post-IPO $(s+)$ is an indicator that equals one if it is $s$ or more years since the firm went public, and Post-1996 is an indicator equal to one for years after 1996. In Panel A, we report the estimates for $y_{i t}$ equal to $\log (S a l e s)$ and Debt/TA. In Panel B, we report the estimates for $y_{i t}$ equal to EBIDTA/Sales and Bankruptcy, where Bankruptcy is an indicator variable that equals 1 in year emph $\{\mathrm{t}$ if the firm files for bankruptcy with the BIFR and 0 otherwise. The IPO data is from SDC while the financial data is from the Prowess database. The sample includes all non-Government and non-foreign firms with assets greater than Rs. 50 million from Prowess for the years 1992-2002, but excludes firms that undertake an IPO after 1996. The standard errors are clustered at individual firm level. ***, **, and * indicate statistical significance at the $1 \%, 5 \%$, and $10 \%$ level.

Panel A: Sales and Leverage

\begin{tabular}{|c|c|c|c|c|}
\hline & \multicolumn{2}{|c|}{$\log ($ Sales $)$} & \multicolumn{2}{|c|}{ Debt/TA } \\
\hline & (1) & $(2)$ & $(3)$ & (4) \\
\hline Post-IPO $(1+) \times$ Post-1996 & & $\begin{array}{c}-.095^{* *} \\
(.045)\end{array}$ & & $\begin{array}{c}.047^{* * *} \\
(.010)\end{array}$ \\
\hline Post-IPO(0) & $\begin{array}{l}-.018 \\
(.043)\end{array}$ & $\begin{array}{l}-.015 \\
(.043)\end{array}$ & $\begin{array}{c}-.061^{* * *} \\
(.008)\end{array}$ & $\begin{array}{c}-.062^{* * *} \\
(.008)\end{array}$ \\
\hline Post IPO (1) & $\begin{array}{c}.184^{* * *} \\
(.043)\end{array}$ & $\begin{array}{c}.201^{* * *} \\
(.044)\end{array}$ & $\begin{array}{c}-.016^{* *} \\
(.008)\end{array}$ & $\begin{array}{c}-.025^{* * *} \\
(.008)\end{array}$ \\
\hline Post IPO (2) & $\begin{array}{c}.311^{* * *} \\
(.044)\end{array}$ & $\begin{array}{c}.355^{* * *} \\
(.050)\end{array}$ & $\begin{array}{l}.017^{*} \\
(.009)\end{array}$ & $\begin{array}{l}-.005 \\
(.010)\end{array}$ \\
\hline Post IPO $(3+)$ & $\begin{array}{c}.341^{* * *} \\
(.050)\end{array}$ & $\begin{array}{c}.426^{* * *} \\
(.061)\end{array}$ & $\begin{array}{c}.052^{* * *} \\
(.011)\end{array}$ & $\begin{array}{c}.010 \\
(.012)\end{array}$ \\
\hline Firm Fixed Effects & $\mathrm{X}$ & $\mathrm{X}$ & $\mathrm{X}$ & $\mathrm{X}$ \\
\hline Year Fixed Effects & $\mathrm{X}$ & $\mathrm{X}$ & $\mathrm{X}$ & $\mathrm{X}$ \\
\hline Obs. & 41030 & 41030 & 42278 & 42278 \\
\hline$R^{2}$ & .863 & .863 & .754 & .754 \\
\hline
\end{tabular}


Panel B: Profits and Bankruptcy Rates

\begin{tabular}{|c|c|c|c|c|}
\hline & \multicolumn{2}{|c|}{ EBIDTA/Sales } & \multicolumn{2}{|c|}{ Bankruptcy } \\
\hline & (1) & $(2)$ & (3) & (4) \\
\hline Post-IPO $(1+) \times$ Post-1996 & & $\begin{array}{c}-.052^{* *} \\
(.022)\end{array}$ & & $\begin{array}{c}.045^{* * *} \\
(.009)\end{array}$ \\
\hline Post-IPO(0) & $\begin{array}{c}-.0004 \\
(.016)\end{array}$ & $\begin{array}{c}.001 \\
(.015)\end{array}$ & $\begin{array}{c}.004 \\
(.005)\end{array}$ & $\begin{array}{c}.003 \\
(.005)\end{array}$ \\
\hline Post IPO (1) & $\begin{array}{l}-.024 \\
(.017)\end{array}$ & $\begin{array}{l}-.015 \\
(.017)\end{array}$ & $\begin{array}{l}.0009 \\
(.005)\end{array}$ & $\begin{array}{l}-.007 \\
(.006)\end{array}$ \\
\hline Post IPO (2) & $\begin{array}{c}-.070^{* * *} \\
(.021)\end{array}$ & $\begin{array}{c}-.046^{* *} \\
(.022)\end{array}$ & $\begin{array}{c}.002 \\
(.006)\end{array}$ & $\begin{array}{c}-.018^{* *} \\
(.008)\end{array}$ \\
\hline Post IPO $(3+)$ & $\begin{array}{c}-.131^{* * *} \\
(.022)\end{array}$ & $\begin{array}{c}-.084^{* * *} \\
(.027)\end{array}$ & $\begin{array}{c}.022^{* * *} \\
(.008)\end{array}$ & $\begin{array}{c}-.018^{*} \\
(.010)\end{array}$ \\
\hline Firm Fixed Effects & $\mathrm{X}$ & $\mathrm{X}$ & $\mathrm{X}$ & $\mathrm{X}$ \\
\hline Year Fixed Effects & $\mathrm{X}$ & $\mathrm{X}$ & $\mathrm{X}$ & $\mathrm{X}$ \\
\hline Obs. & 41030 & 41030 & 42278 & 42278 \\
\hline$R^{2}$ & .421 & .421 & .485 & .487 \\
\hline
\end{tabular}




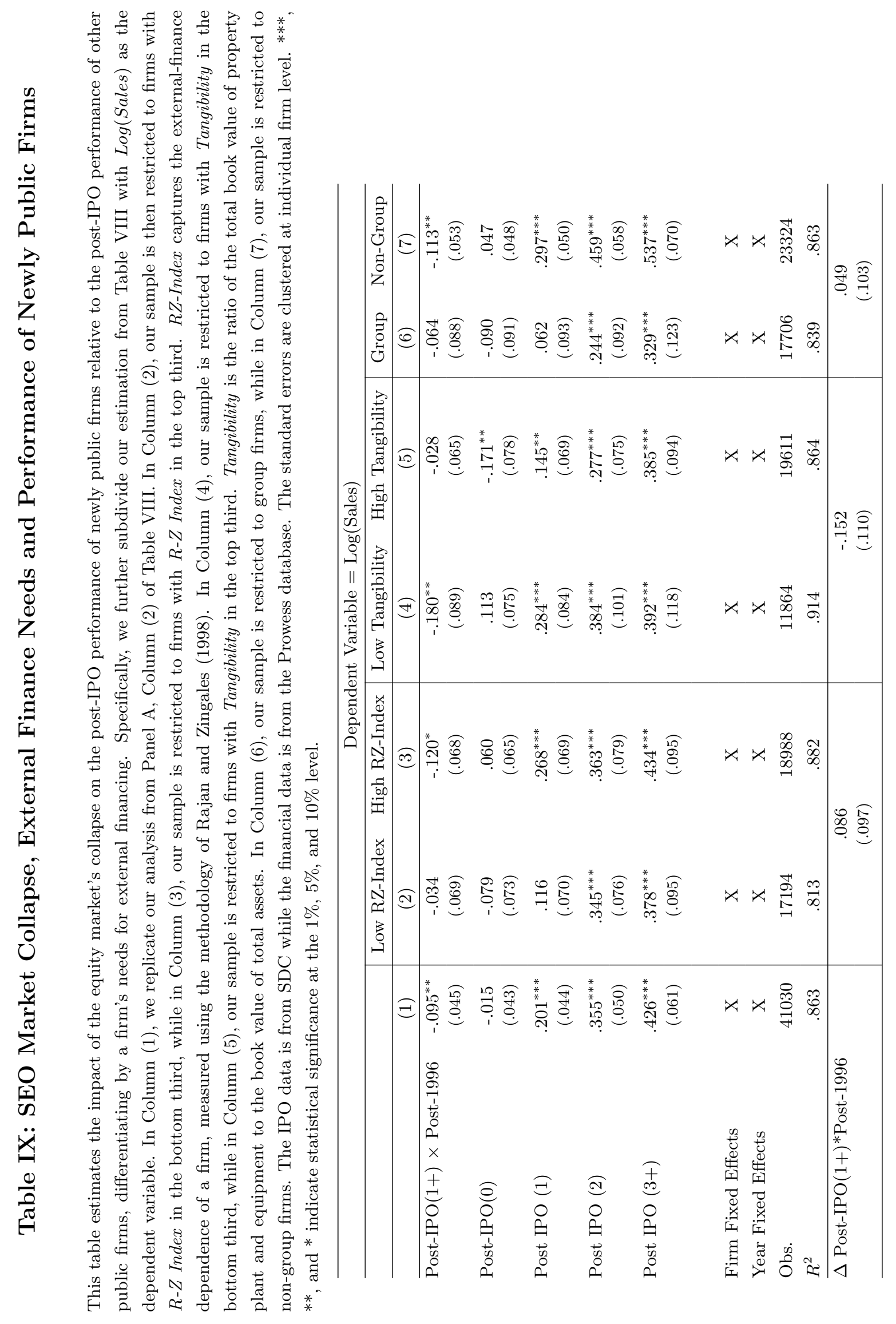




\section{Appendix I - Definitions}

1. Total Assets is the book value of total assets in units of Rs. 10 million.

2. Sales is the total sales in units of Rs. 10 million.

3. Sales Growth is the growth rate of sales.

4. Capital Expenditure is the ratio of the investment in property plant and equipment to the book value of gross fixed assets.

5. EBIDTA/TA is the ratio of earnings before interest depreciation taxes and amortization to total assets.

6. EBIDTA/Sales is the ratio of earnings before interest depreciation taxes and amortization to total sales.

7. Trade Credit/Sales is the ratio of accounts payable to total sales.

8. Debt/TA is the ratio of book value of total borrowing to the book value of total assets.

9. Industry Market-to-Book is the median ratio of market value of total assets to book value of total assets of all firms in an industry.

10. Age is firm age since incorporation measured in number of years.

11. Group is a dummy variable that takes a value 1 for firms that belong to a business group.

12. Tangibility is the ratio of the total book value of property plant and equipment to the book value of total assets.

13. Industry Investment is the median investment by all firms in an industry, where investment is the rate of growth of gross fixed assets.

14. RZ-Index is a measure of the external-finance dependence of a firm. It is measured using the methodology of Rajan and Zingales (1998).

15. Post-1996 IPO is a dummy variable that takes a value 1 for firms that go public after 1996 and 0 for the other firms.

16. $I P O$ is a dummy variable that takes a value 1 in the year in which a firm goes public

17. Post-IPO (Year $i$ ) is a dummy variable that takes a value 1 in Year $i$ after the IPO and 0 otherwise.

18. Post 1996 is a dummy variable that takes a value 1 for the period after 1996 and 0 otherwise.

19. $\operatorname{Pr}(I P O)$ is the predicted probability of a private firm doing an IPO.

20. $\operatorname{Pr}(S E O)$ is the predicted probability of a public firm doing an SEO.

21. $\operatorname{Pr}(S E O)$ is the predicted probability of a public firm doing an SEO.

22. Bankruptcy is an indicator variable that equals 1 in year $t$ if the firm files for bankruptcy with the BIFR and 0 otherwise. 


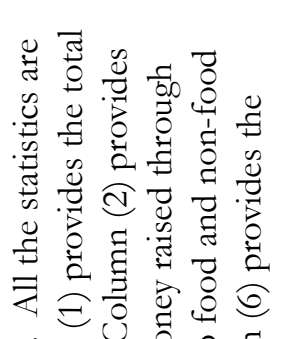

范



궁

胥

ล

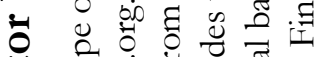

嵌

क

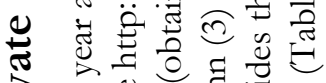

.

․

-

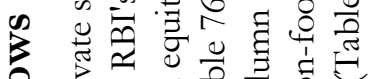

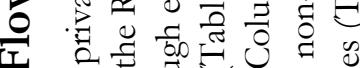

I

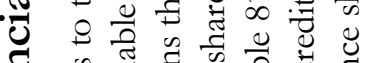

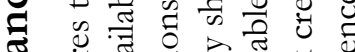

:

تُ

击

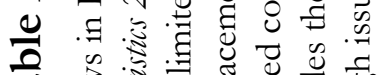

을

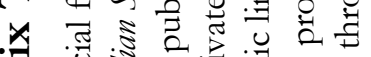

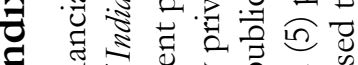

ए

द्र

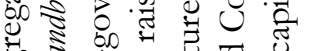

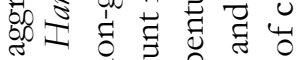

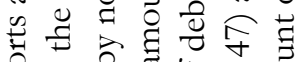

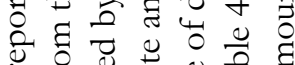
Ð

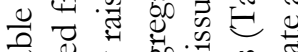
ङิ छै



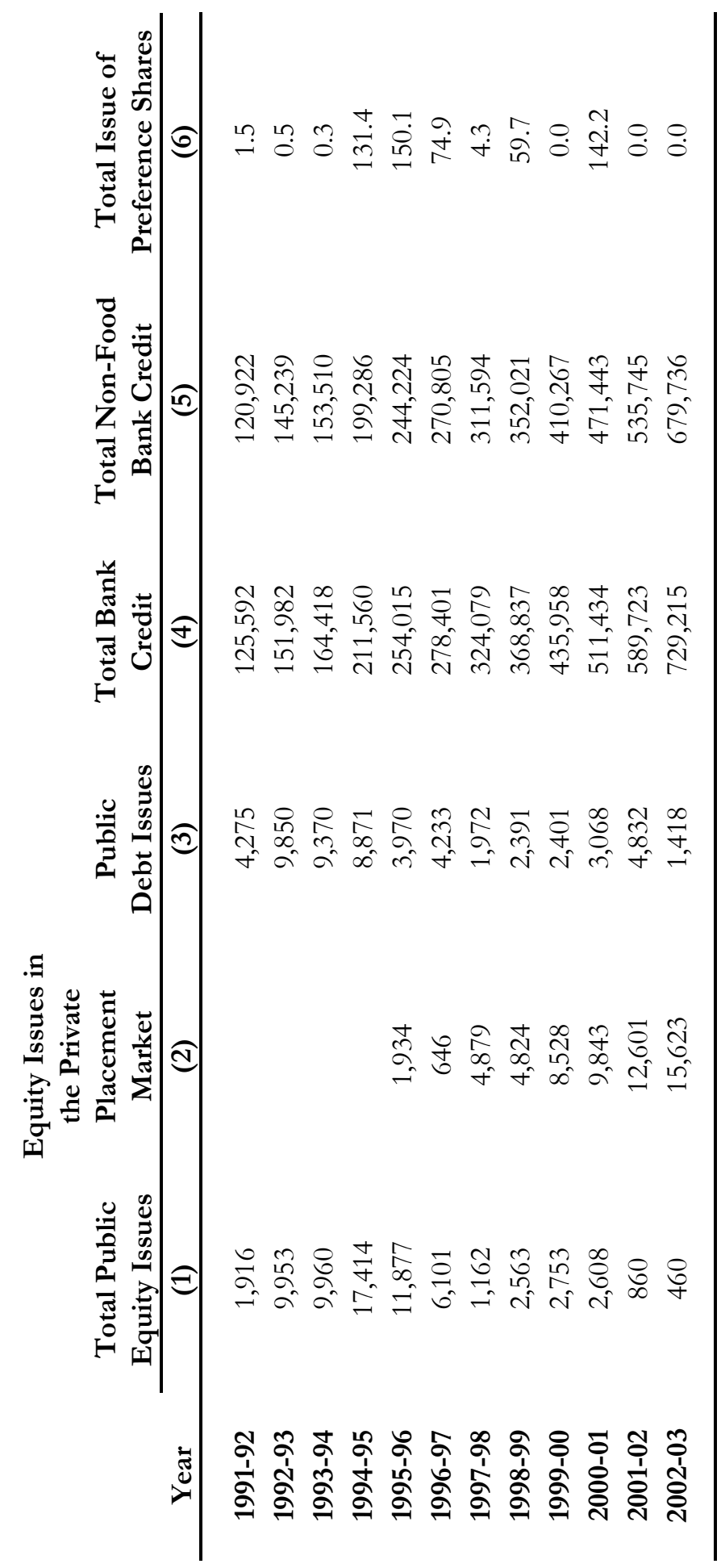




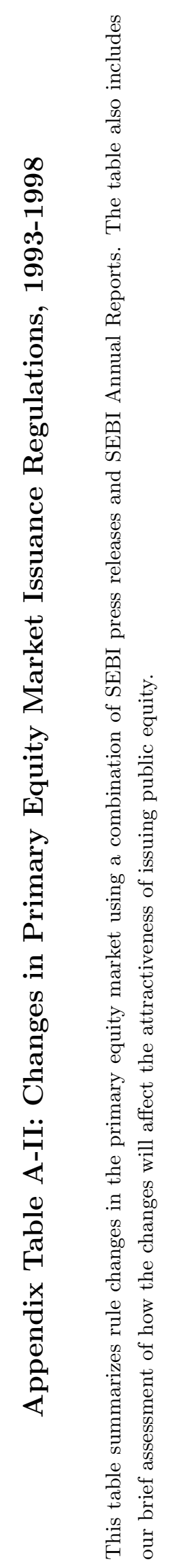




\begin{tabular}{|c|c|c|c|c|c|c|c|c|}
\hline 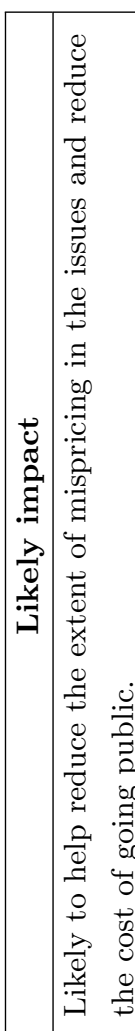 & 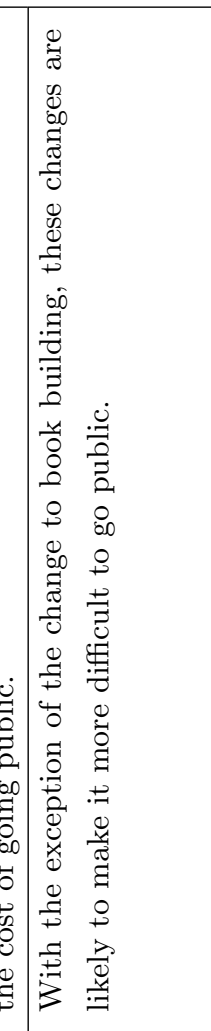 & 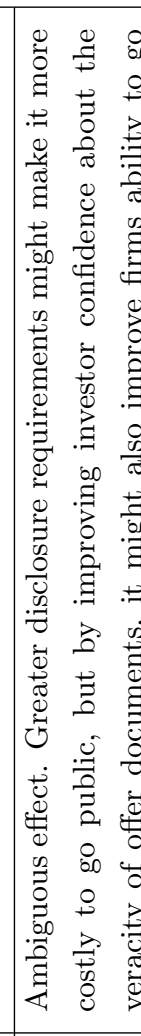 & 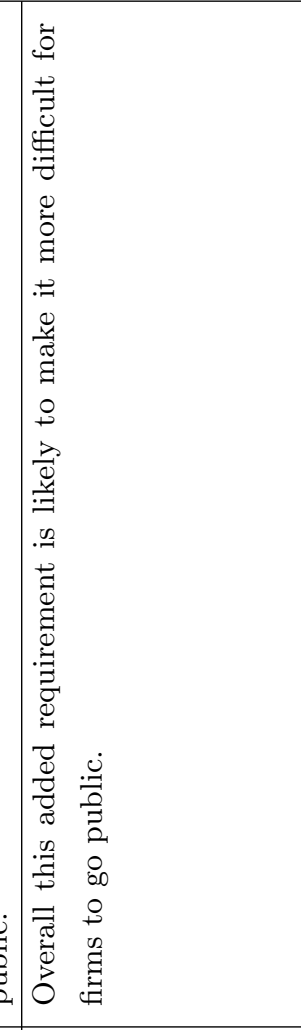 & 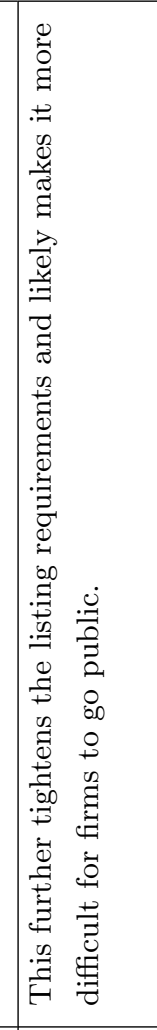 & 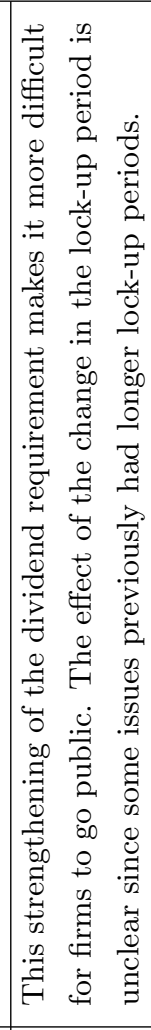 & 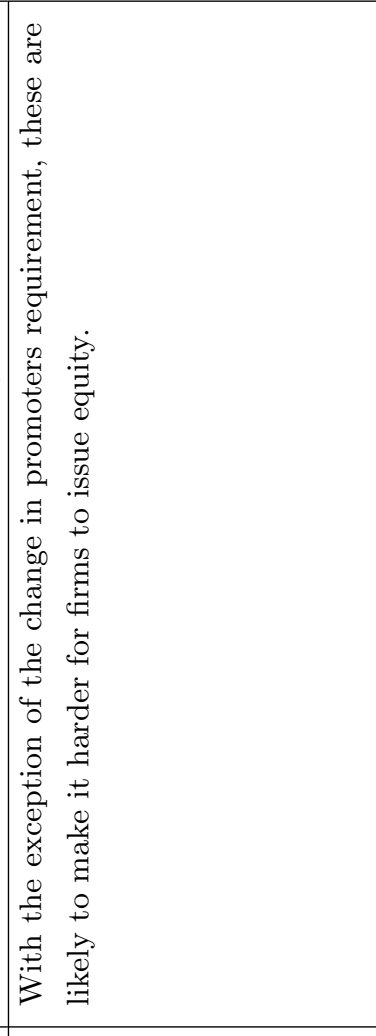 & 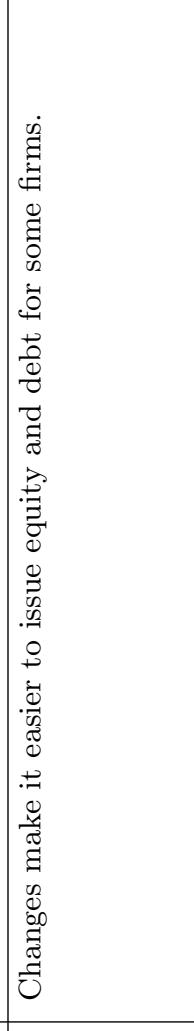 & 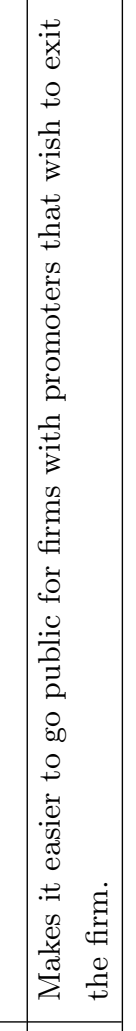 \\
\hline 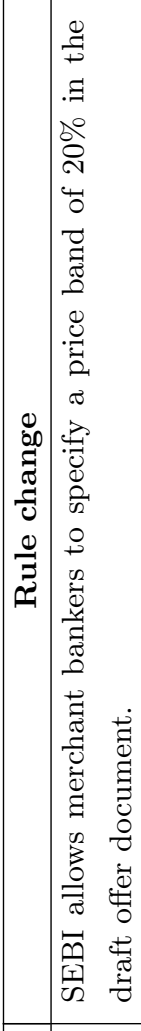 & 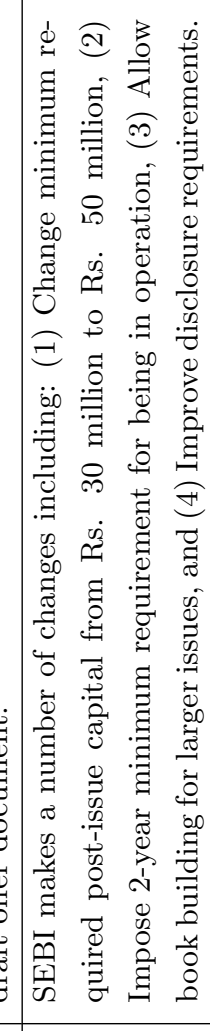 & 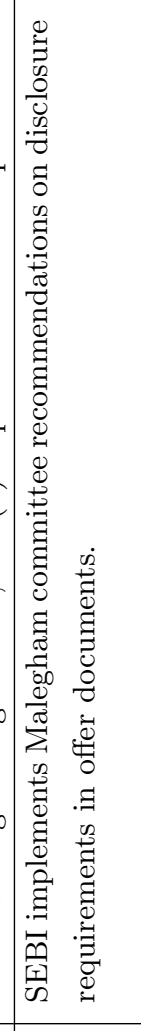 & 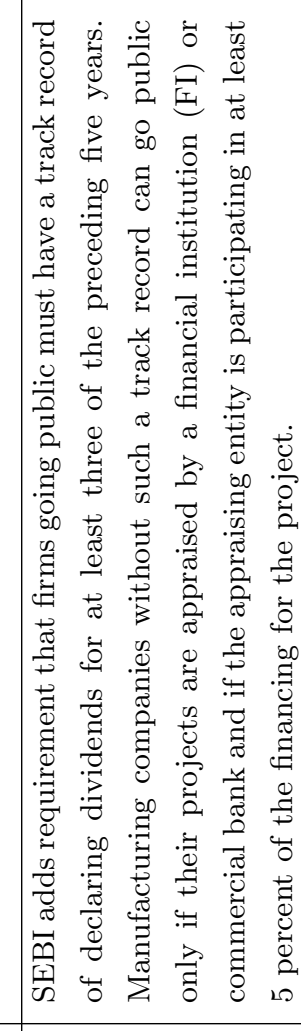 & 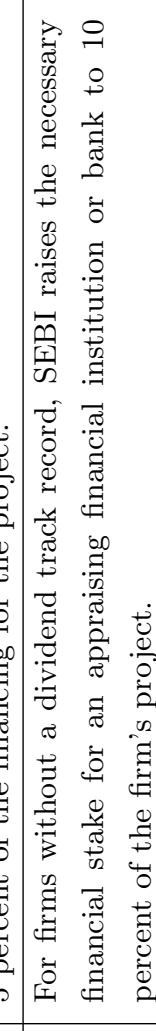 & 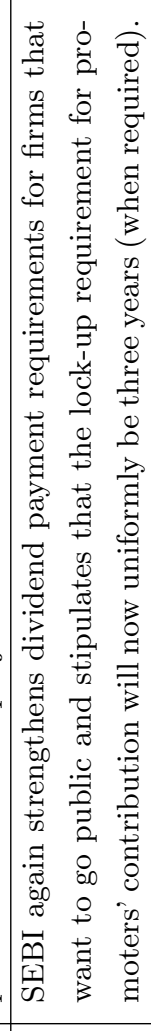 & 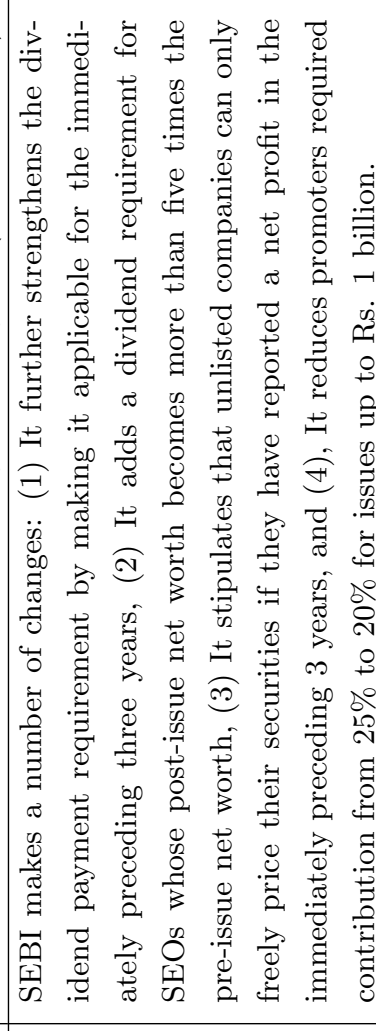 & 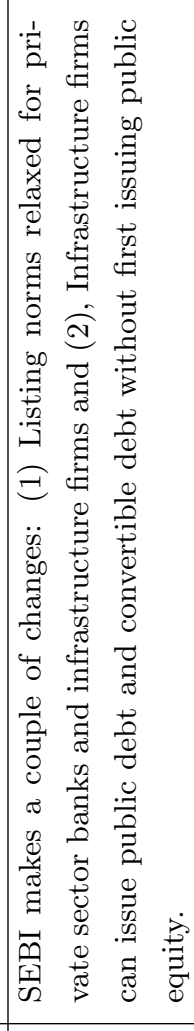 & 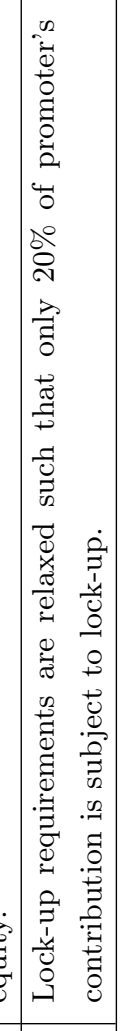 \\
\hline 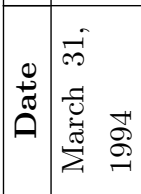 & $\stackrel{g}{g}$ & 8 & 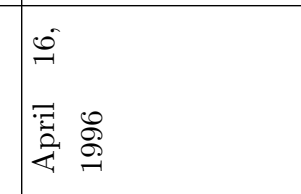 & 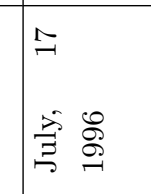 & 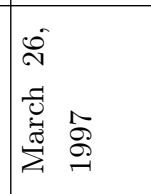 & & & \\
\hline
\end{tabular}

